\title{
Cumarin, 藥物學的作用
}

\author{
賴 其 禄
}

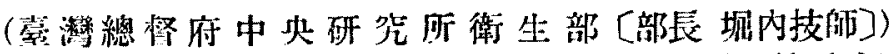

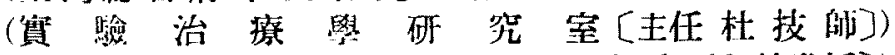

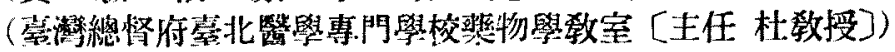

(昭和十年共月十七日受付)

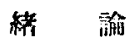

保驗材料

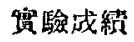

I. 一般现象=及ボス作网

1. 水蛙二於ヶ几实驗

2. Maus =於ヶル蛅路

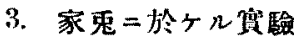

4. 厡蜔蛅二於ヶ几惯驗

II. 家鬼ノ呼吸及ビ血滕二Z゙ボス 作月]

III. 心脿=及ボス作月I

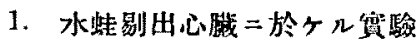

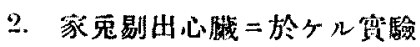

IV. 血管二及ボス作用
次

1. 水蛙媵肢血管二於ヶル䁈驗

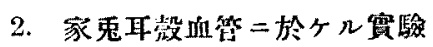

3. 家鬼督践血管二於ヶ儿筷羷

4. 家鬼冠快血管二於ヶ几富驗

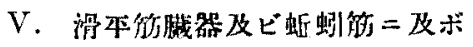
又作用

1. 家香剔出腸管二於ヶ几赛驗

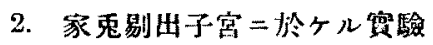

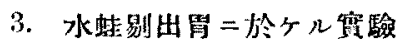

4. 水赫剔出腸管二於ヶル惯驗

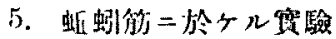

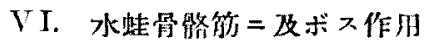

概 括

可用書日

緒論

Cumarin $\left(\mathrm{C}_{9} \mathrm{H}_{6} \mathrm{O}_{2}=\mathrm{C}_{6} \mathrm{H}_{4}<\mathrm{O}-\mathrm{CO}=\mathrm{CH}\right)$ (

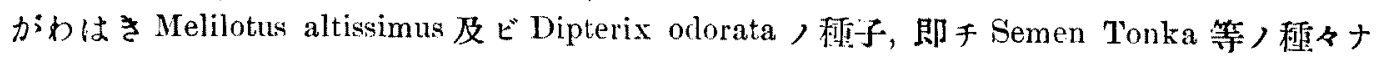
ル植物中二含有シ或ハ人几的二合成七ルモノニシテ传快ナル香氣高キチ以テ屡々香味炓或 八防臭劑, 例へバ Chloroform, Formalin 或ハJodoform 等)惡臭 7 镉息スル二使用スルコト

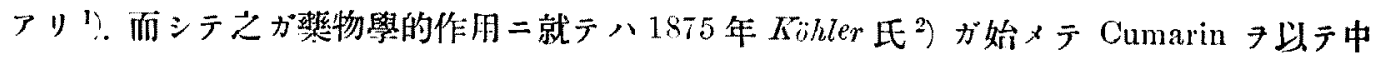

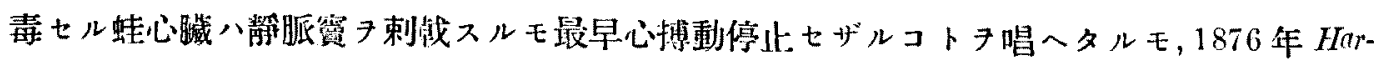

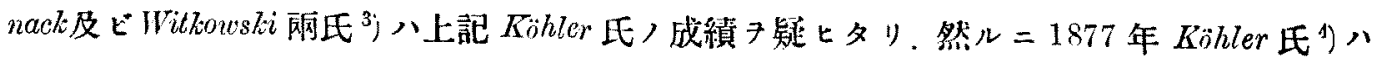

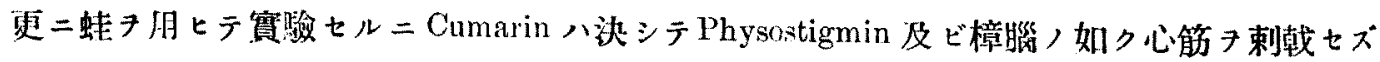

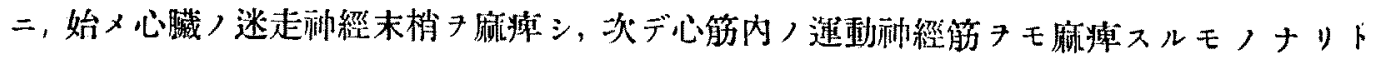
云七タリ. 1895年 Winternitz 氏占) 八犬二汗射シテ體温が上昇シ及ビ白血球八最初減少セル

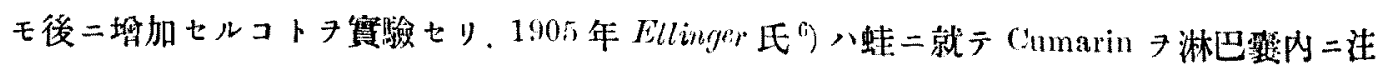




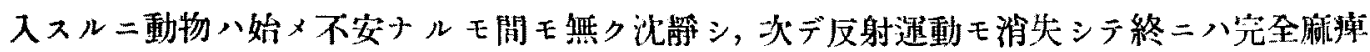
二陷り，又蝴蚪二於テ八稀薄ナル溶液 $(1: 14000)=\mp モ 10-15$ 分後二八接觸二對三反隼

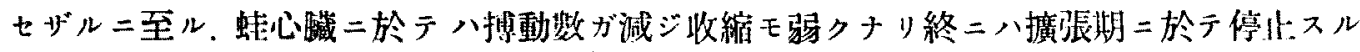

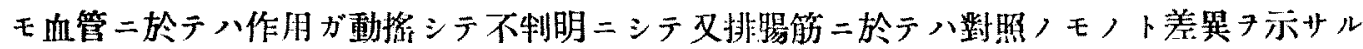

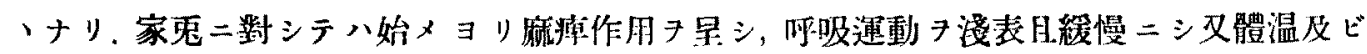

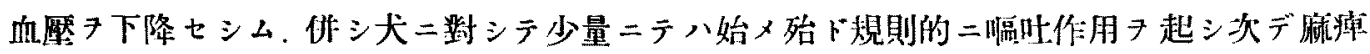

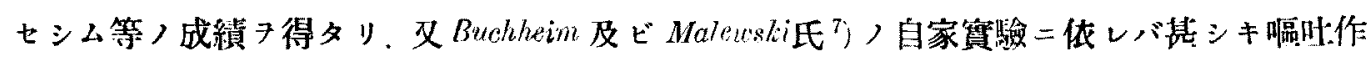

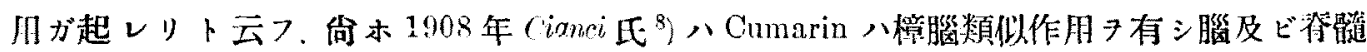

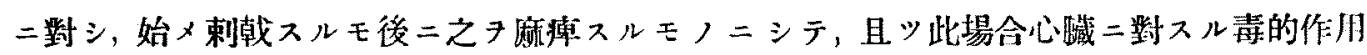

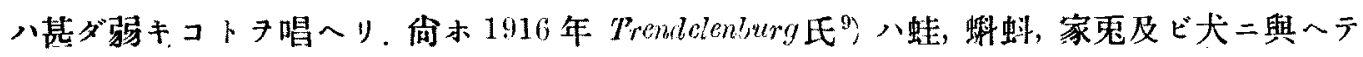

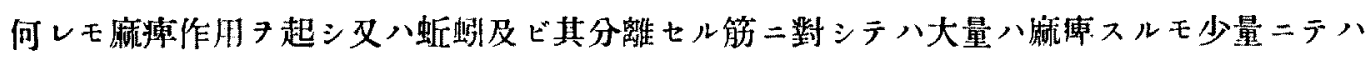

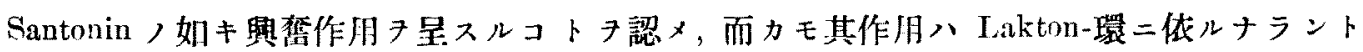
唱へタリ。

如斯Cumarin ，藥物學的作用二就テ八今迄主トシテ動物ノ一般中毒症状7檢七ル二止 マリ，而モ其所話必ラズシモ相一致スル二非ズ，殊二剔出臟器二就テ，賽臉八基ダ少シ。

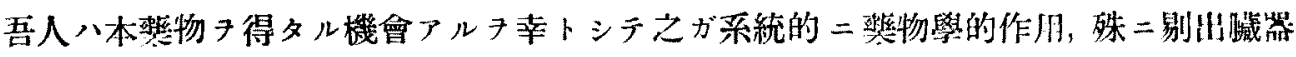

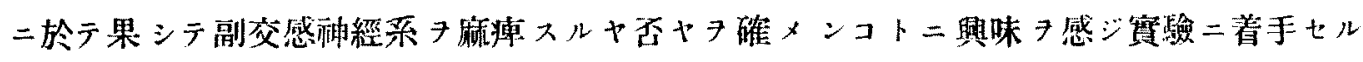
ナリ.

\section{實 驗 材 料}

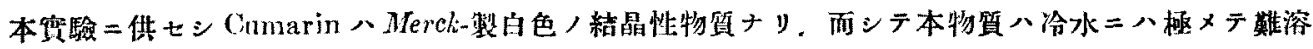

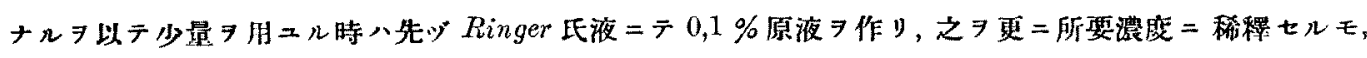

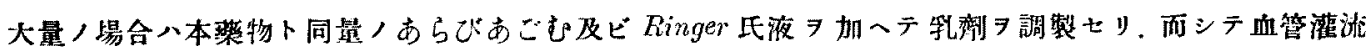
ニ用フル菜液八何レモ原液 $习$ 滤過七り。

\section{實 驗 成 綪}

\section{I. 一般現象二及ボス作用}

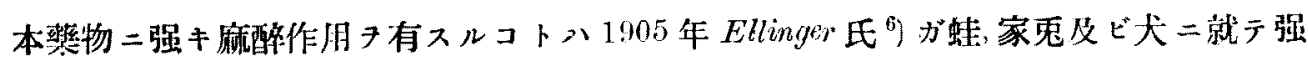

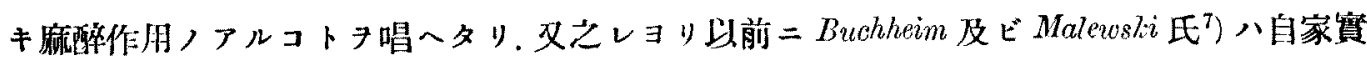

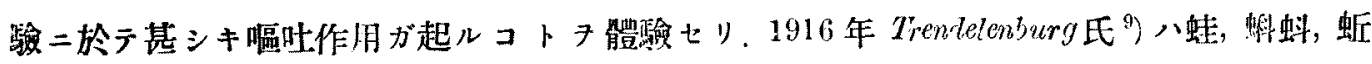
蚓，家鬼及ビ犬二於テ認メタリ。

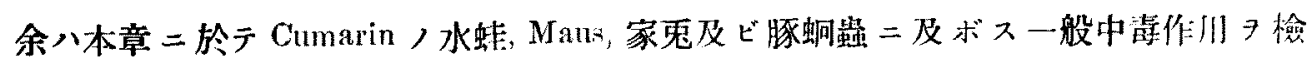
セリ. 


\section{1. 水蛙二於ケル實駱}

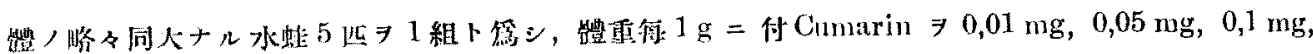

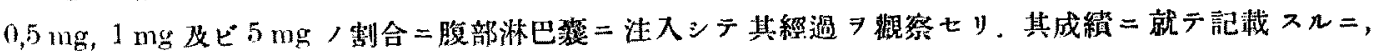

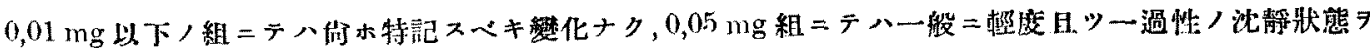

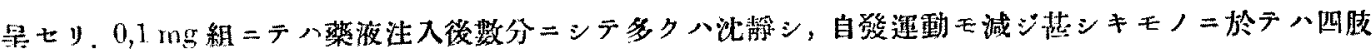

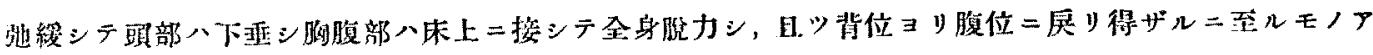

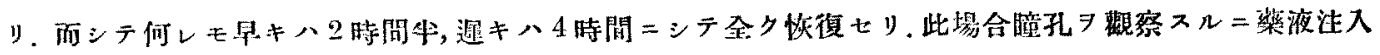

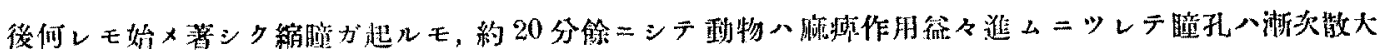

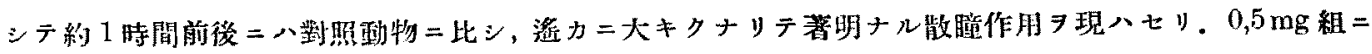

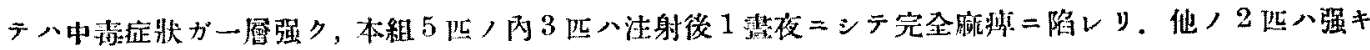

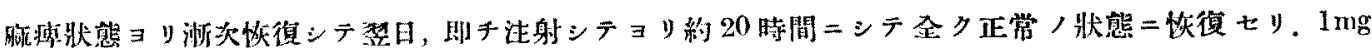

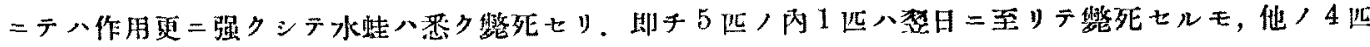

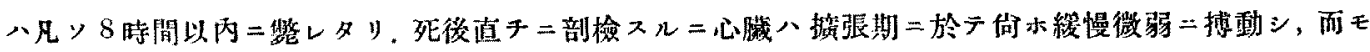

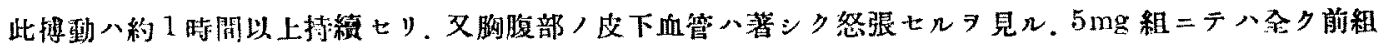

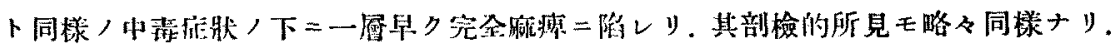

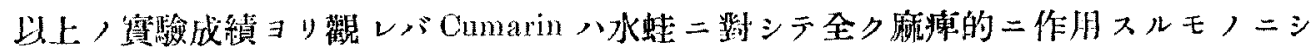

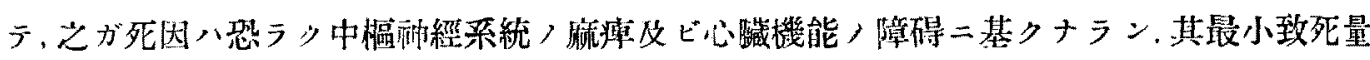

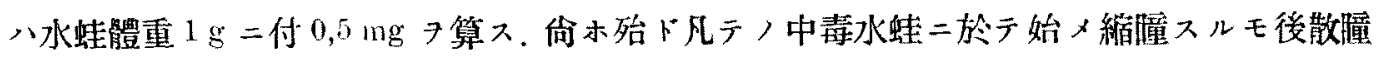
作用チ現ハスコトハ注目スベキ默ナリ。

向ホ上記，筫羷成綨キ表示スレバ第 1 表，邚シ.

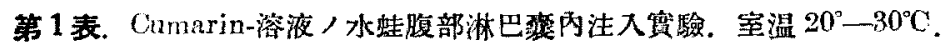

\begin{tabular}{|c|c|c|c|c|c|c|}
\hline 香 啒 & 性 & 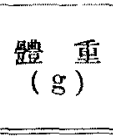 & 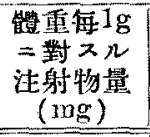 & 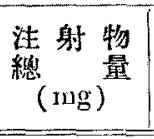 & 結 & 摘 \\
\hline 1 & $\hat{o}$ & 53 & 0,01 & 0,53 & 罢常ナを & \\
\hline 2 & $\$$ & 48 & 0,01 & 0,48 & $"$ & \\
\hline 3 & $\delta$ & 48 & 0,01 & 0,48 & $"$ & \\
\hline 4 & $\hat{o}$ & 47 & 0,01 & 0,47 & $"$ & \\
\hline 5 & 今 & 42 & 0,01 & 0,42 & $"$ & \\
\hline 6 & 3 & 29 & 0,05 & 1,45 & 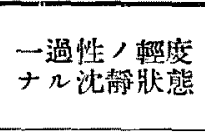 & 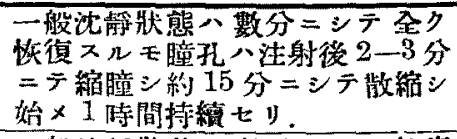 \\
\hline 7 & $\hat{\delta}$ & 31 & 0,05 & 1,55 & $"$ & 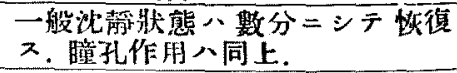 \\
\hline 8 & $\delta$ & 29 & 0,05 & 1,45 & $"$ & 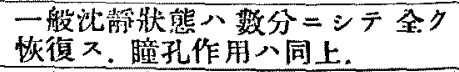 \\
\hline 9 & $\delta$ & 25 & 0,05 & 1,25 & $"$ & 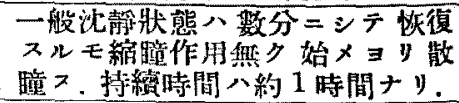 \\
\hline 10 & $\hat{\delta}$ & 26 & 0,05 & 1,30 & $"$ & 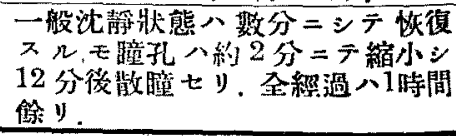 \\
\hline
\end{tabular}




\begin{tabular}{|c|c|c|c|c|c|c|}
\hline 蛊 號 & 性: & $\left(\begin{array}{c}\text { 蹧 } \\
(\mathrm{g})\end{array}\right.$ & 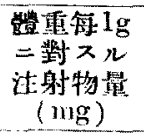 & 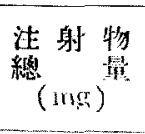 & 維 & 防 \\
\hline 11 & 울 & 48 & 0,10 & 1,80 & $\begin{array}{l}\text { 中等度／沈靜 } \\
\text { 狀留 }\end{array}$ & 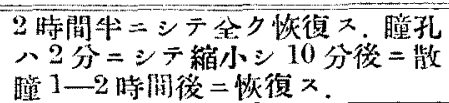 \\
\hline 12 & 3 & 46 & 0,10 & 4,60 & " & 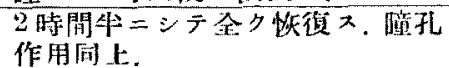 \\
\hline 13 & $\delta$ & 45 & 0,10 & 4,50 & 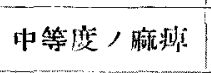 & $\begin{array}{l}3 \text { 時間 }=シ テ \text { 全っ㤆復ス。瞕孔作 } \\
\text { 用同上. }\end{array}$ \\
\hline 14 & $\delta$ & 43 & 0,10 & 4,30 & $"$ & 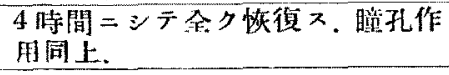 \\
\hline 15 & 우 & 40 & 0,10 & 4,00 & $"$ & 同上 \\
\hline 16 & $\delta$ & 59 & 0,50 & 29,5 & 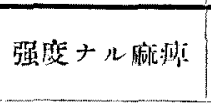 & 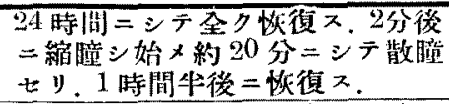 \\
\hline 17 & $\hat{\delta}$ & 56 & 0,50 & 28,0 & $"$ & $\begin{array}{l}24 \text { 時間=シテ 全ク恢復ス。瞳孔 } \\
\text { 作洞同上. }\end{array}$ \\
\hline 18 & $\hat{\delta}$ & 56 & 0,50 & 28,0 & 死（20 時閒） & 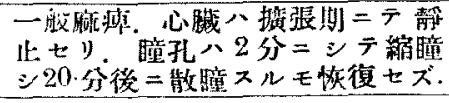 \\
\hline 19 & 甲 & 55 & 0,50 & 27,5 & 死(1壱夜以內) & 同上 \\
\hline 20 & $q$ & 5,4 & 0,50 & 27,0 & " & 同上 \\
\hline 21 & $\hat{\delta}$ & 72 & 1,00 & 72,0 & $"$ & 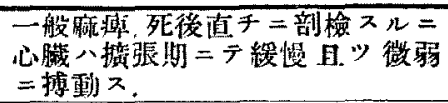 \\
\hline 22 & $\delta$ & 69 & 1,00 & 69,0 & 死 (8 時間) & 同上 \\
\hline 23 & $\delta$ & 68 & 1,00 & 68,0 & , & 同上 \\
\hline 24 & $\hat{\delta}$ & 60 & 1,00 & 60,0 & 死 (6 時間) & 同上 \\
\hline 25 & $\delta$ & $\tilde{5} 7$ & 1,00 & 57,0 & $"$ & 同上 \\
\hline 26 & q & 67 & 5,00 & 335,0 & 死 (32 分閒) & 同上 \\
\hline 27 & $\delta$ & 67 & 5,00 & 335,0 & 死（26 分閒） & 同上 \\
\hline 28 & $\delta$ & 64 & 5,00 & 320,0 & 死 (20 分閒) & 同上 \\
\hline 29 & $\xi$ & 64 & 5,00 & 320,0 & $"$ & 同上 \\
\hline 30 & $\delta$ & 60 & 5,00 & 300,0 & 死 (18 分閒) & 同上 \\
\hline
\end{tabular}

\section{Maus ニ於ケル苗験}

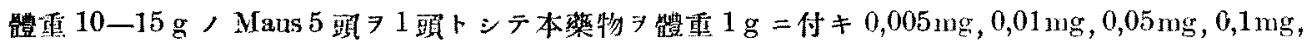

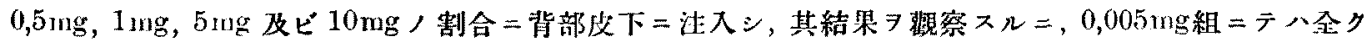

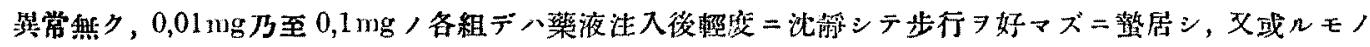

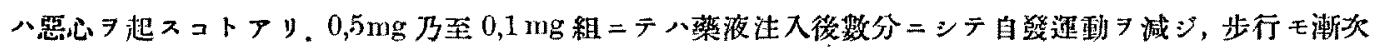

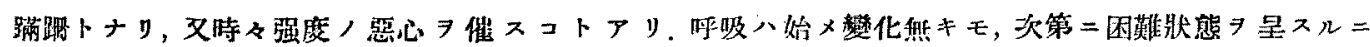

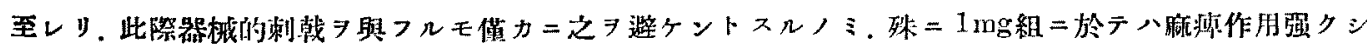

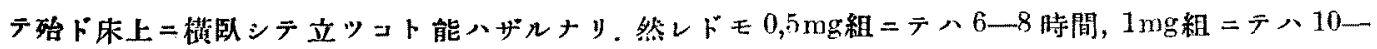

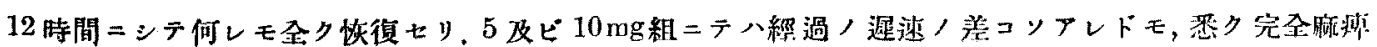




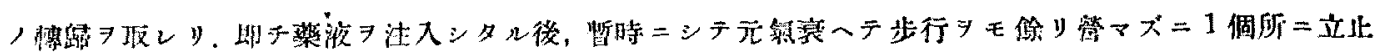

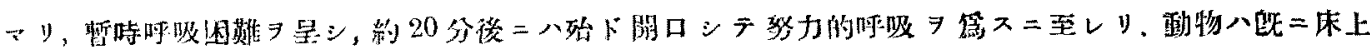

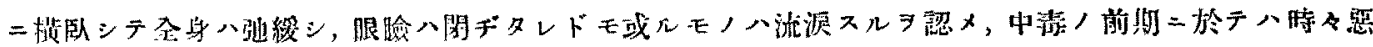

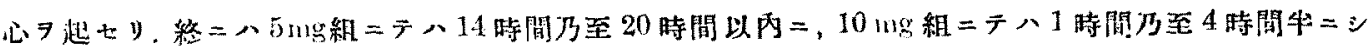

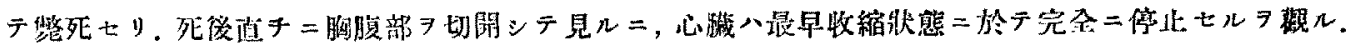

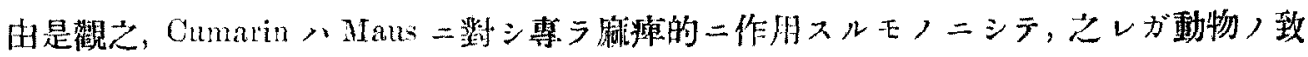

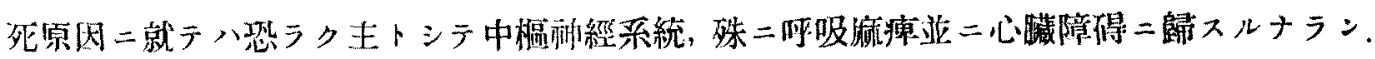

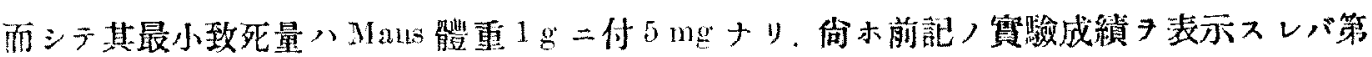
2 表, 姆三。

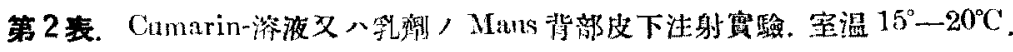

\begin{tabular}{|c|c|c|c|c|c|c|}
\hline 潘 號 & 性 & 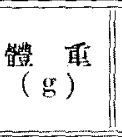 & 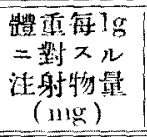 & 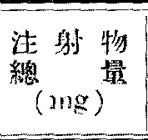 & 粘累 & 倣 \\
\hline 1 & q & 19 & 0,005 & 0,065 & 思常ナシ & \\
\hline 2 & $q$ & 12 & 0,005 & 0,06 & $"$ & \\
\hline 3 & $\hat{o}$ & 12 & 0,005 & 0,06 & $"$ & \\
\hline 4 & $q$ & 11 & 0,005 & 0,055 & $"$ & \\
\hline 5 & $t$ & 11 & 0,005 & 0,$115 ;$ & $"$ & \\
\hline 6 & $\delta$ & 11 & 0,01 & 0,11 & 整 $\neq$ 沚鲑 & 4-5分=シテ全ク恢復ス。 \\
\hline 7 & $q$ & 11 & 0,01 & 0,11 & $"$ & 同上 \\
\hline 8 & $\delta$ & 10 & 0,01 & 0,10 & $"$ & 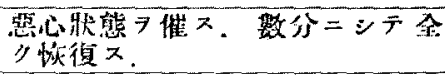 \\
\hline 9 & $\delta$ & 10 & 0,01 & 0,10 & $"$ & 同上 \\
\hline 10 & q & 10 & 0,01 & 0,10 & $"$ & 同上 \\
\hline 11 & 8 & 13 & 0,05 & 0,65 & ", & 同上: \\
\hline 12 & 9 & 13 & 0,05 & 0,65 & $"$ & 同上 \\
\hline 1.9 & $\delta$ & 13 & 0,05 & 0,65 & $"$ & 同上 \\
\hline 14 & $\delta$ & 12 & 0,05 & 0,60 & 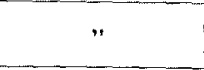 & $7-8$ 分ニシテ全タ惔得ス。 \\
\hline 15 & 9 & 12 & 0,05 & 0,60 & $"$ & 同上 \\
\hline 16 & $\delta$ & 10 & 0,1 & 1,0 & " & 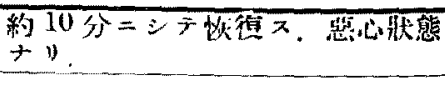 \\
\hline 17 & 9 & 10 & 0,1 & 1,0 & " & 同5: \\
\hline 18 & \& & 10 & 0,1 & 1,0 & $"$ & 同上 \\
\hline 19 & $q$ & 10 & 0,1 & 1,0 & $"$ & 同上 \\
\hline 20 & $\hat{o}$ & 10 & 0,1 & 1,0 & $"$ & 同上: \\
\hline 21 & 9 & 12 & 0,5 & 6,0 & 中等度, 瞅流 & 6 時間 ニシテ全ク炏復 $。$. \\
\hline
\end{tabular}




\begin{tabular}{|c|c|c|c|c|c|c|}
\hline 采 諕 & 性 & 體 & 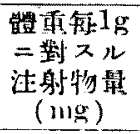 & 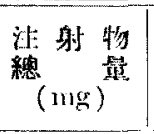 & 絬 & 摘 \\
\hline 22 & $\delta$ & 12 & 0,5 & 6,0 & 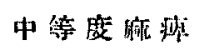 & 6 時間卅 ニシテ全ク怢得ス。 \\
\hline 23 & q & 11 & 0,5 & 5,5 & $"$ & 闹上 \\
\hline 24 & q & 11 & 0,5 & 5,5 & $"$ & 7 時間ニシテ全ク恢復ス。 \\
\hline 35 & $\delta$ & 11 & 0,5 & 5,5 & $"$ & 8 洔間 ニシテ全ク恢復ス。 \\
\hline 26 & $\hat{o}$ & 14 & 1,0 & 14,0 & 强 $\neq$ 麻埧 & 10 時間 =シテ全タ矤得ス。 \\
\hline 27 & $\delta$ & 14 & 1,0 & 14,0 & $"$ & 11 時間ニシテ全ク恢復ス。 \\
\hline 28 & $\hat{\delta}$ & 13 & 1,0 & 13,0 & $"$ & 同上 \\
\hline 29 & 웅 & 13 & 1,0 & 13,0 & $"$ & 同上 \\
\hline 30 & q & 13 & 1,0 & 13,0 & $"$ & 12 時間 ニシテ企ク恢復ス。 \\
\hline 31 & $\delta$ & 12 & 5,0 & 60,0 & 死 (14 時開) & 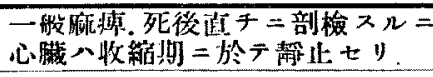 \\
\hline 32 & $q$ & 12 & 5,0 & 60,0 & $"$ & 同上 \\
\hline 33 & $q$ & 11 & 5,0 & 55,0 & 死（16 洔間） & 同上 \\
\hline 34 & 웅 & 11 & 5,0 & 55,0 & $"$ & 同上 \\
\hline 35 & 3 & 11 & 5,0 & $5 \overline{,}, 0$ & 死 (20 時間) & 同上 \\
\hline 36 & $\delta$ & 15 & 10,0 & 150,0 & 死（1洔间件） & 同上 \\
\hline .37 & $\delta$ & 15 & 10,0 & 150,0 & 死 (2 時閒) & 同上 \\
\hline 38 & q & 14 & 10,0 & 140,0 & 死 (3 洔 間) & 同上 \\
\hline 39 & $q$ & 12 & 10,0 & 120,0 & 死（4 㭙間） & 同上 \\
\hline 40 & 우 & 10 & 10,0 & 100,0 & $"$ & 同上 \\
\hline
\end{tabular}

\section{3. 家鬼ニ於ケル寞驗}

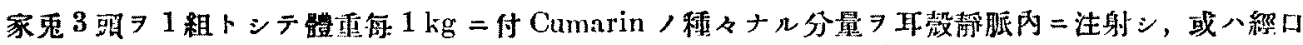

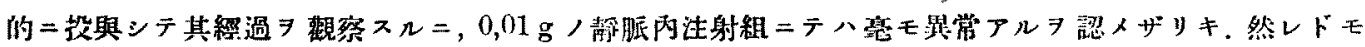

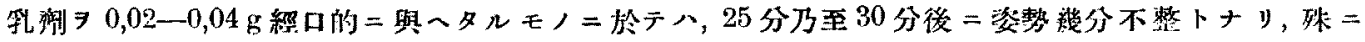

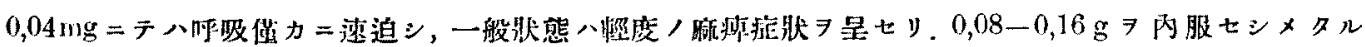

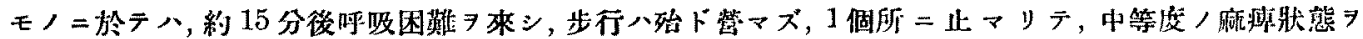

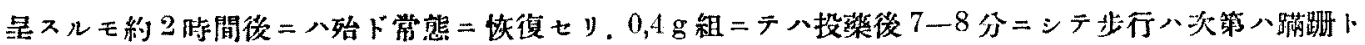

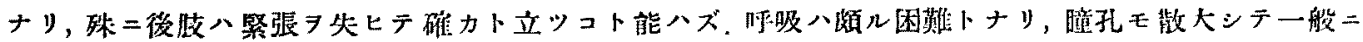

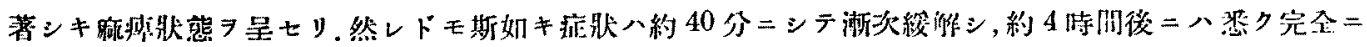

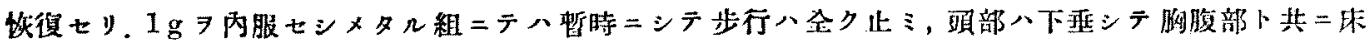

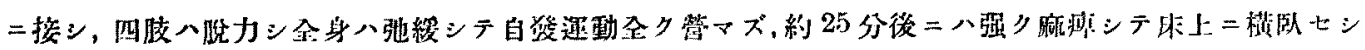

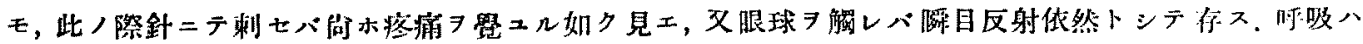

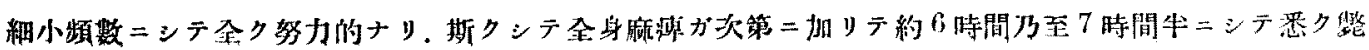




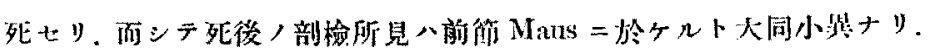

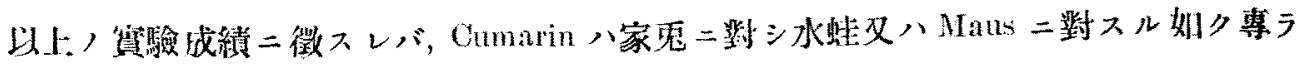

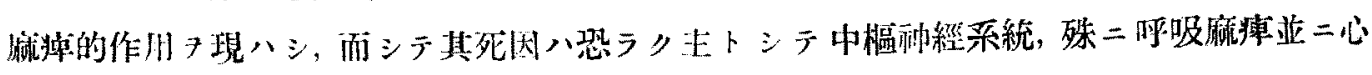

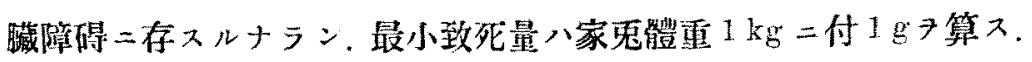

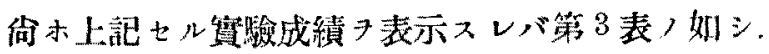

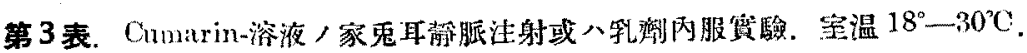

\begin{tabular}{|c|c|c|c|c|c|c|}
\hline 番 號 & 性: & $\stackrel{(\mathrm{kg})}{\text { 體 }}$ & 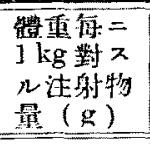 & $\begin{array}{l}\text { 核射物 } \\
\text { 總 } \\
(\mathrm{g})\end{array}$ & 粘棸 & 摘 \\
\hline 1 & $\hat{\delta}$ & 1,25 & 0,01 & 0,0125 & 綎 化ナシ & \\
\hline 2 & $\delta$ & 2,20 & 0,01 & 0,022 & $"$ & \\
\hline 3 & q & 2,00 & 0,01 & 0,020 & $"$ & \\
\hline 4 & $\delta$ & 2,10 & 0,02 & 0,042 & 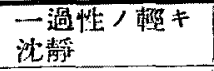 & 制分=シテ性徣ス。 \\
\hline 5 & $\varepsilon$ & 2,10 & 0,02 & 0,042 & $"$ & 同上 \\
\hline 6 & $\delta$ & 2,00 & 0,02 & 0,04 & $"$ & 同上 \\
\hline 7 & $q$ & 2,00 & 0,04 & 0,08 & 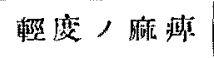 & 20 分ニシテ快佰又。 \\
\hline 8 & 8 & 2,10 & 0,04 & 0,084 & $"$ & 同上 \\
\hline 9 & q & 2,20 & 0,04 & 0,088 & $"$ & 30 分ニシテ恢復ス. \\
\hline 10 & $\delta$ & 1,50 & 0,08 & 0,120 & 中等度，潟瘦 & 1 時間ニシテ全ク板復ス。 \\
\hline 11 & 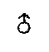 & 2,10 & 0,08 & 0,168 & $"$ & 同上 \\
\hline 12 & $\delta$ & 2,25 & 0,08 & 0,180 & $"$ & 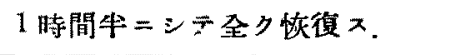 \\
\hline 13 & $q$ & 1,45 & 0,16 & 0,232 & $"$ & 同上 \\
\hline 14 & $q$ & 2,00 & 0,16 & 0,320 & $"$ & 同上 \\
\hline 15 & $\hat{o}$ & 1,50 & 0,16 & 0,240 & $"$ & 2 時間 シシデ全ク恢復ス。 \\
\hline 16 & 9 & 2,25 & 0,40 & 0,900 & 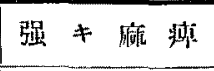 & 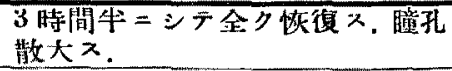 \\
\hline 17 & $\odot$ & 1,50 & 0,40 & 0,600 & $"$ & 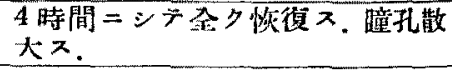 \\
\hline 18 & $\vec{b}$ & 1,45 & 0,40 & 0,580 & $"$ & 同上 \\
\hline 19 & q & 2,00 & 1,00 & 2,00 & 死 (6 時間) & 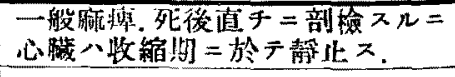 \\
\hline 20 & 古 & 2,00 & 1,00 & 2,00 & 死（7時闒） & 同上 \\
\hline 21 & $\delta$ & 2,10 & 1,00 & 2,10 & $"$ & 同上 \\
\hline
\end{tabular}

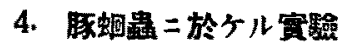

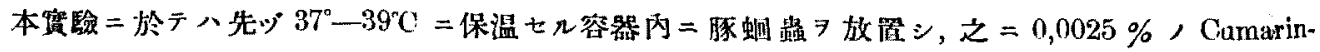

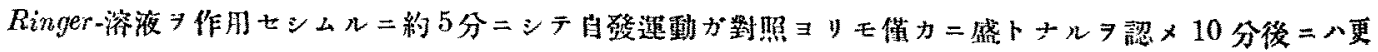




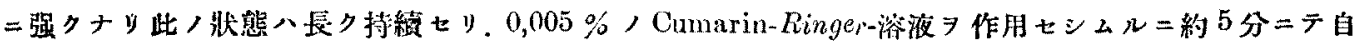

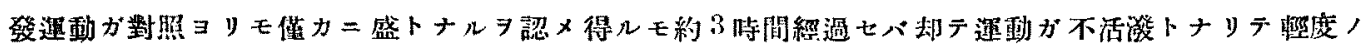

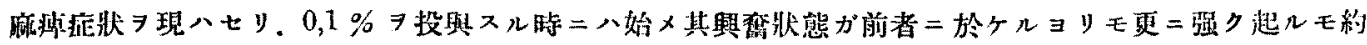

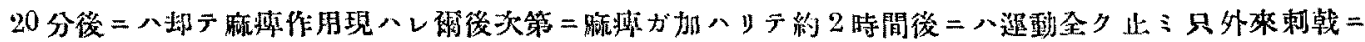

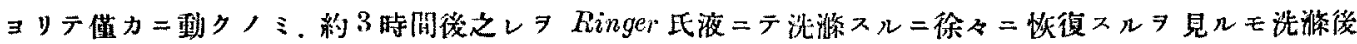

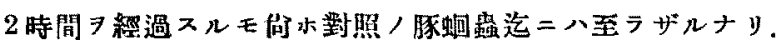

以上ノ成績二依レバ Cumarin，豚蜔䖪二對シ小量二於テハ興舊的二作朋シ，大量二

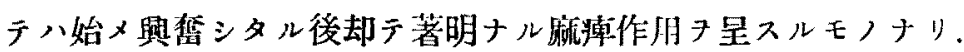

\section{II. 家鬼ノ呼吸及ビ血壓二及ボス作用}

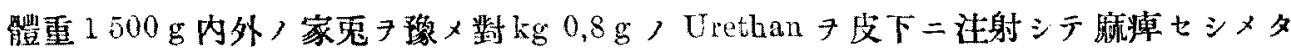

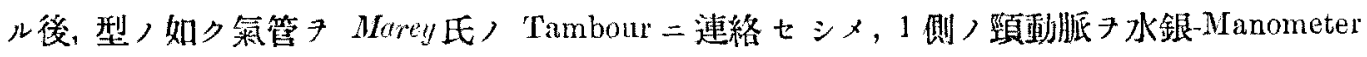

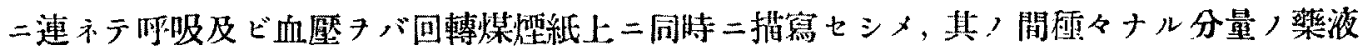

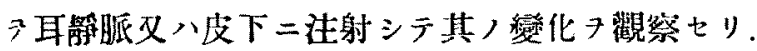

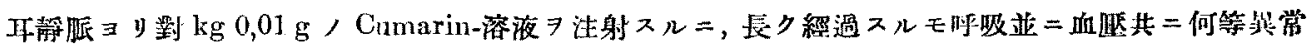

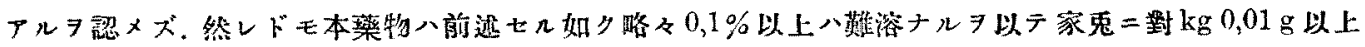

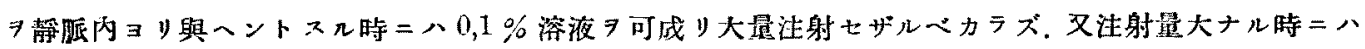

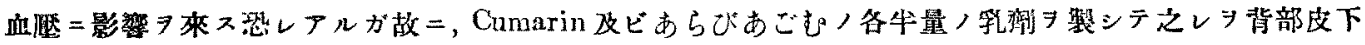

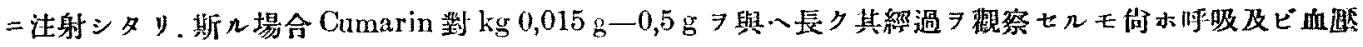
=變化

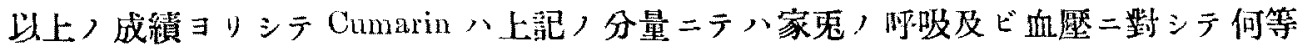
作用ヨ起サザルナり。

\section{1. 心滑二及ホス作用}

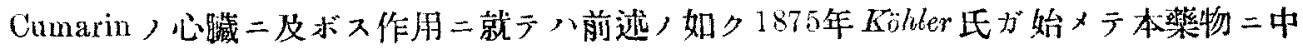

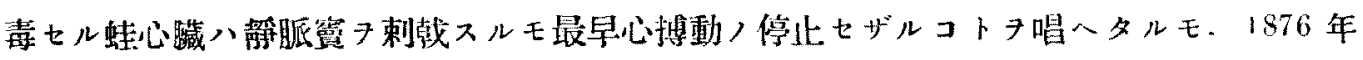

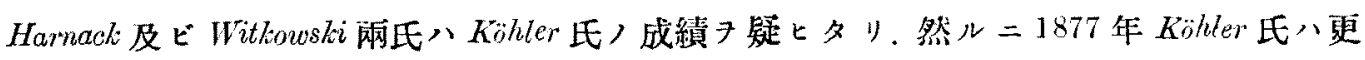
二蛙丹用七テ賽羷セルニCumarin ハ決シテPhysostigmin 及ビ樟腦ノ如ク心筋キ刺戟七大゙

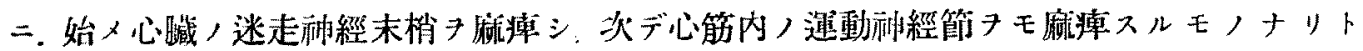
追加報告七り。而シテ 1905 年 Ettinger 氏八又蛙心臟二就テ本樂物心心搏動數尹減少シ收

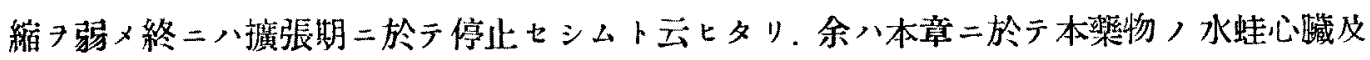

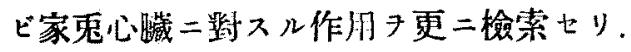

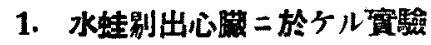

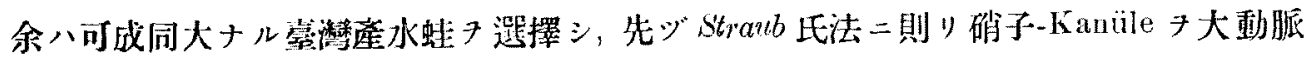

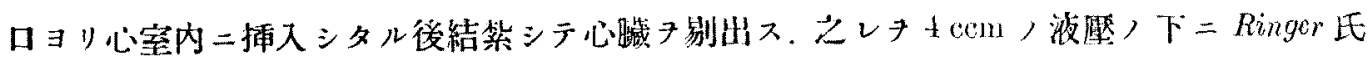

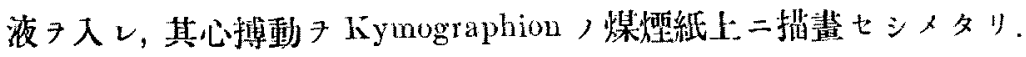

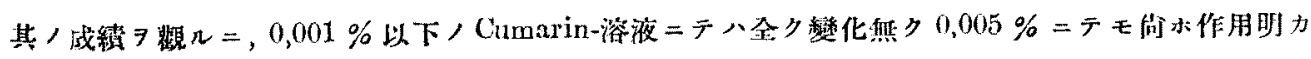


ナラズ，只藥液作用後搏動数稍々減少スルモノアルシ見ルコトアリ。0,01\%ニテハ藥液交換後間モナタ

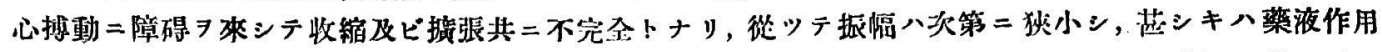

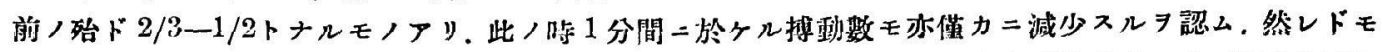

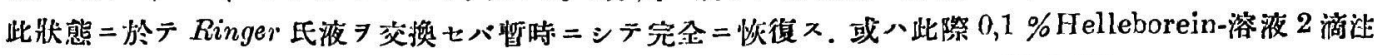

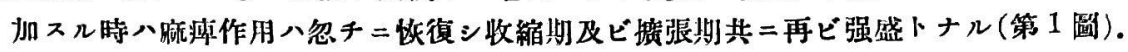

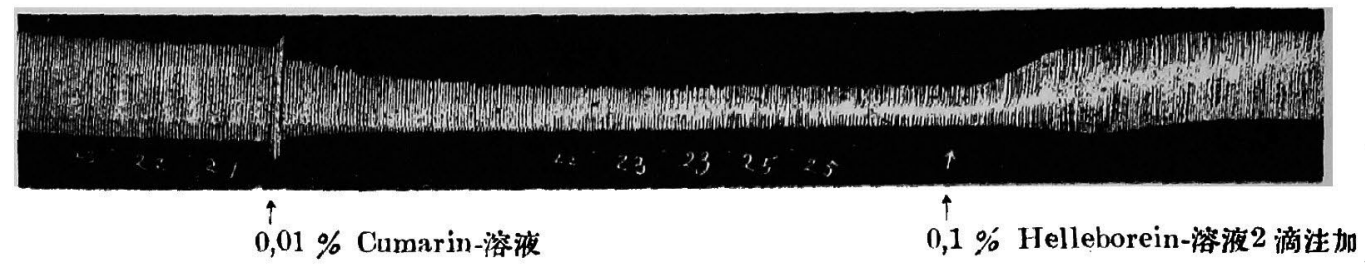

第 1 圖. 水蛙心臟曲線。

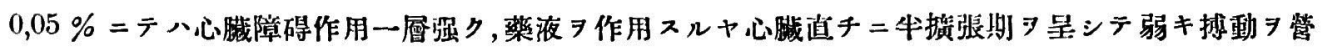
ム二至リ，此場合二於ヶ几报幅八僅力菜夜作用前， $1 / 3$ 以下トナ几. 而シテ斯几状態 是七几モノ二,

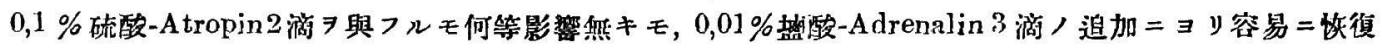

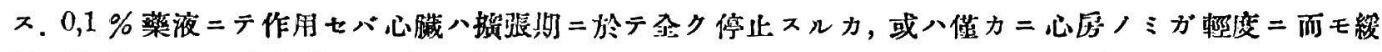

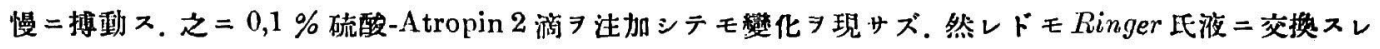

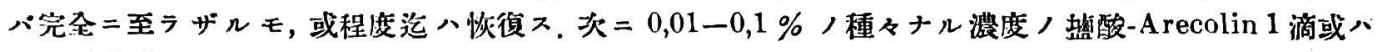

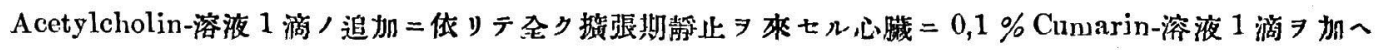

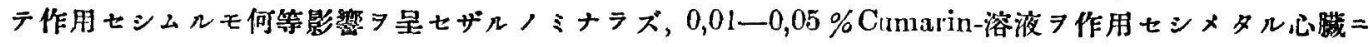

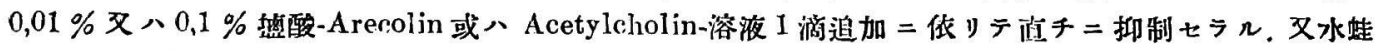

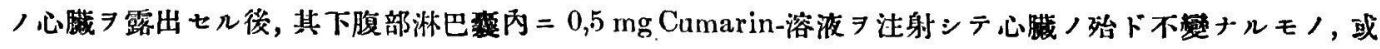

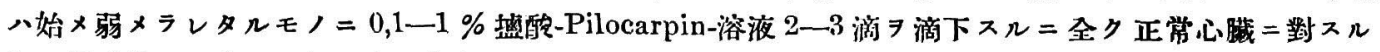
如ク捕動停止 來シ, 次デ再ビ搏動 營メリ。

余八更二感烣需流

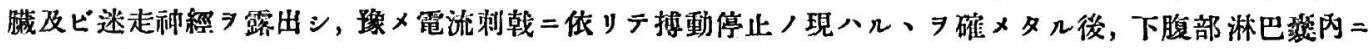

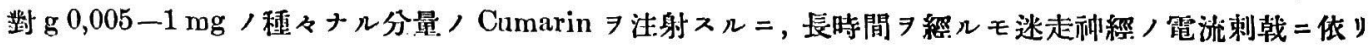
テ依然トシテ搏動停止 ヨ來ス。

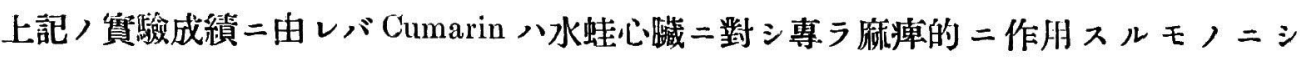
テ，而モ其作用點二就テハ本藥物二テ作月シタル心臟入其迷走神經刺戟ニヨリテ依然トシ

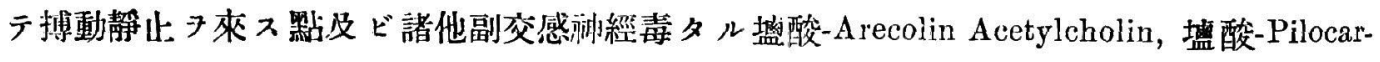
pin 及ビ酒石酸-Nicotin 卜何等抬抗作朋無キ默等: リ考フレバ Köhler 氏ノ說々ル初×迷走

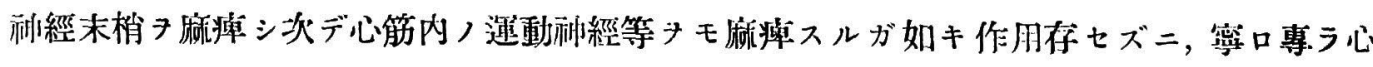

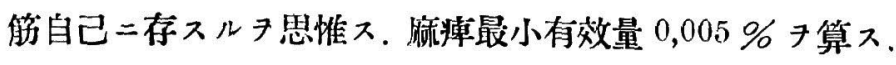

\section{2. 家鬼剔出心蕞二於ケル宽驗}

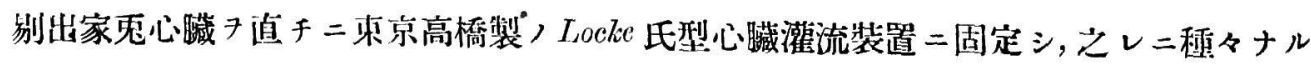
濃度, Cumarin-溶液 7 作朋七シメタリ。

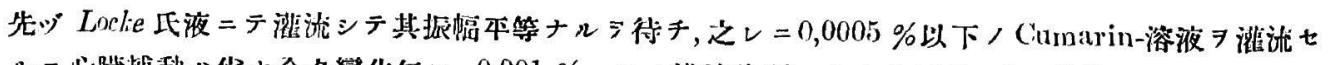

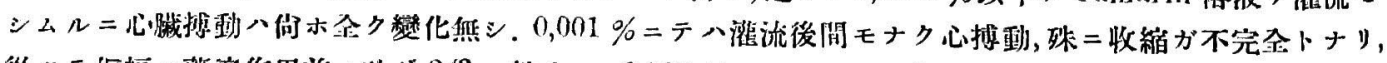

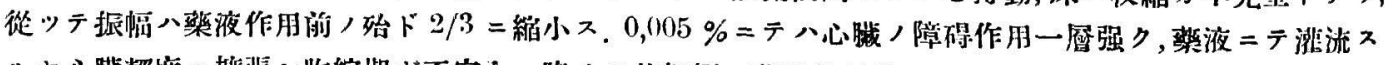

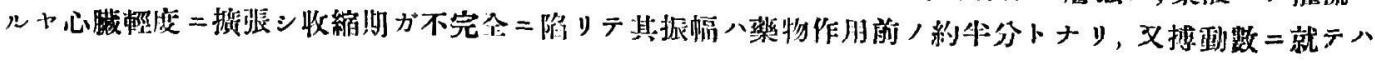




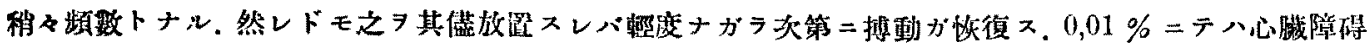

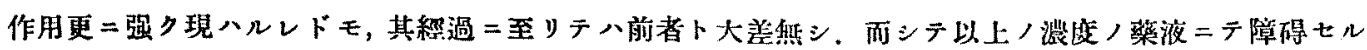

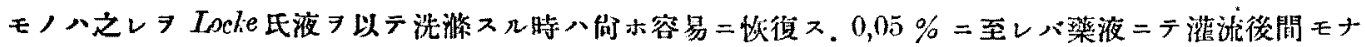

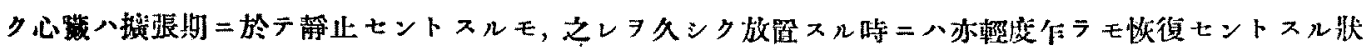

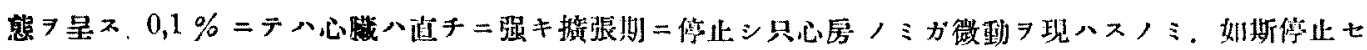

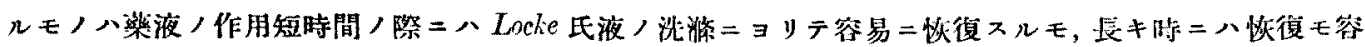
易ナラザルナリ。

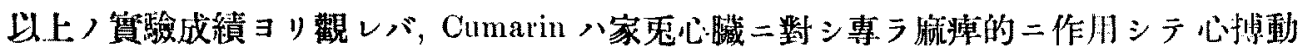
ヨ障碍乃至停止:二至ラシム．其鼠小有效量ハ $0,001 \%$ \%。

\section{IV. 血管二及ボス作用}

Cumarin ，血管二及ボス作朋二關シテハEllinger 氏ガ蛙，浮遊膜血管二就テ檢七シモ

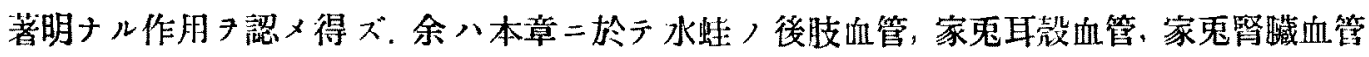

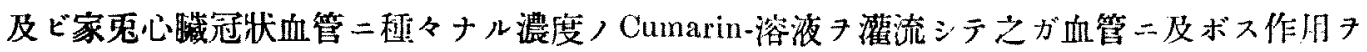
研索七り。其際凡テ，實驗八室温 $25^{\circ}-30^{\circ} \mathrm{C}$ 二於テ行七，1 筫驗八總亏灌流法二從七，先ヅ

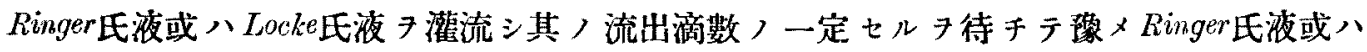
Locke氏液二テ溶解セル䒚液尹以テ交代灌流セリ。

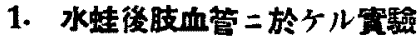

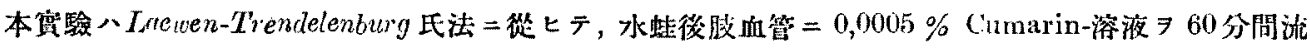

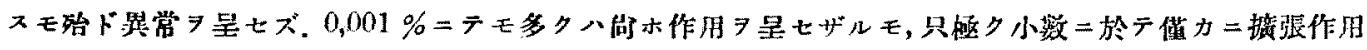

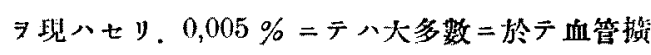

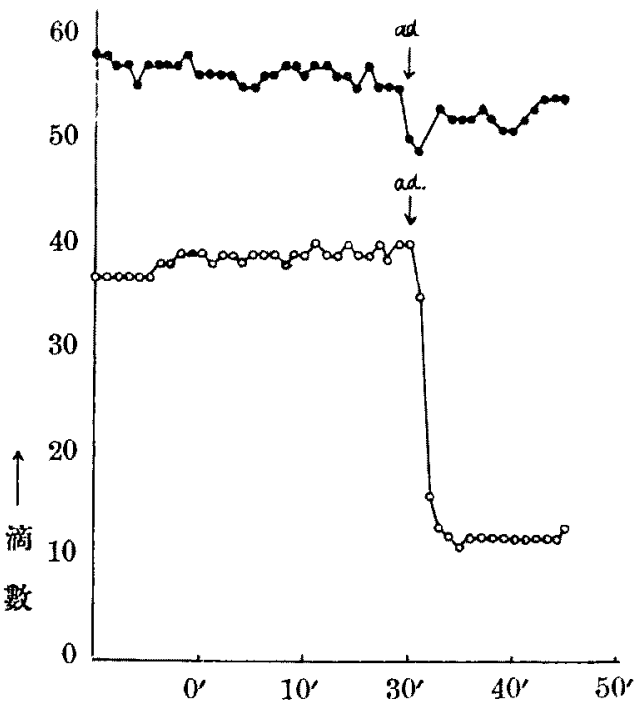

第 2 圆. 水蛙後抆血管襍流。

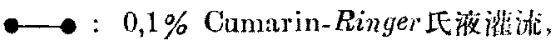

- - o : 正常-Ringer 代滺流,

ad. : $0,0001 \%$ Adrenalin-液 $1 \mathrm{ccm}$ 注入.

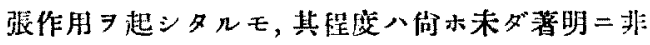

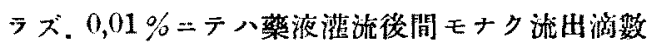

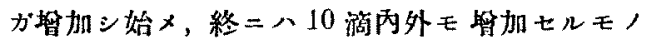

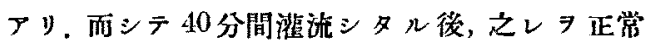
Ringer 氏液二撸一几時八又渏次恢得ス几ヨ認么。

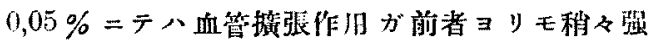

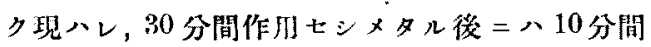

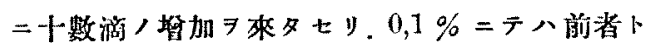
大同小琵ナり。

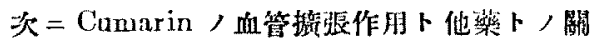
倸 7 見 $ル=, 0,01-0,05 \%$ 硫酸-Atropin 730 分

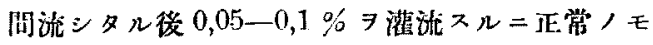

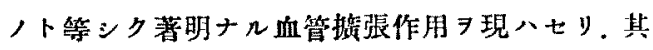
他监酸-Adrenal in 又八Chlorbarium =對ス几荘

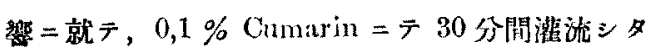
$n € \prime=0,0001 \%$ 瑟酸 Adrenalin 或 $、 0,1 \%$ Chlorbariun $1 \mathrm{ccm} 7$ 让雅ス几㻉二八其血管收

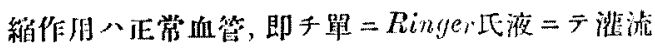

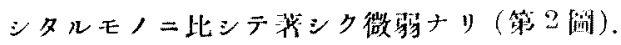




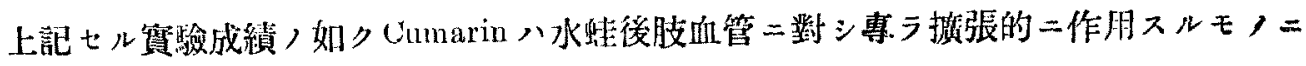

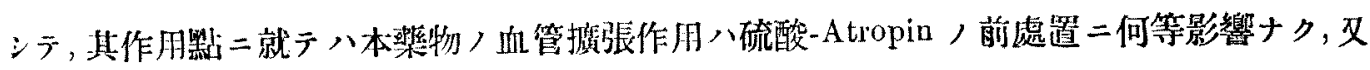

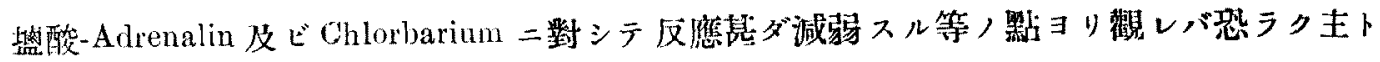

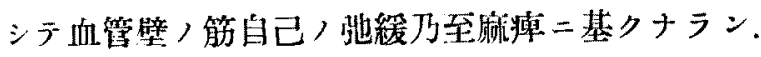

\section{2. 家鬼耳数血菅ニ於ケル惯驗}

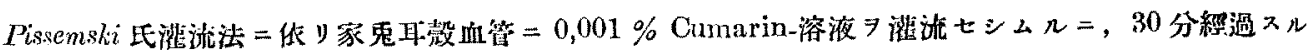

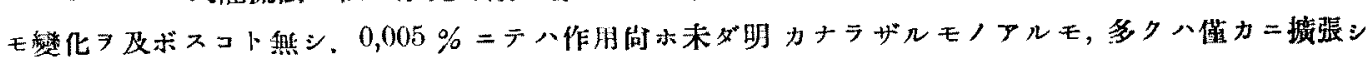

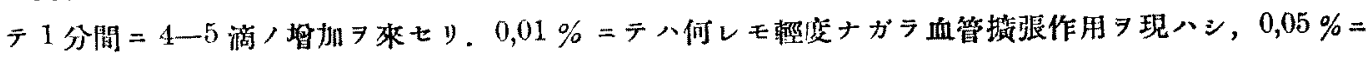

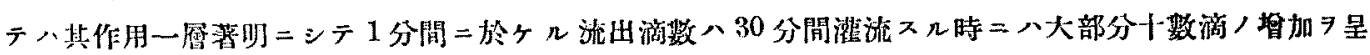

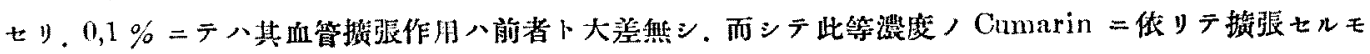

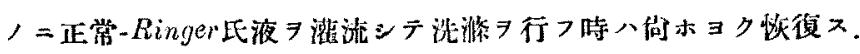

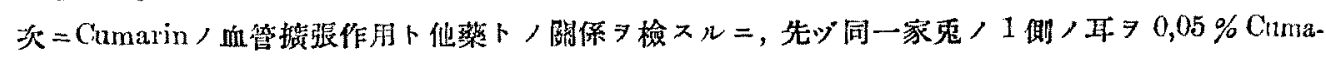

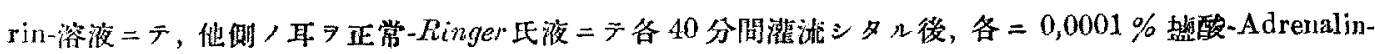

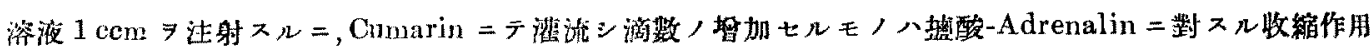

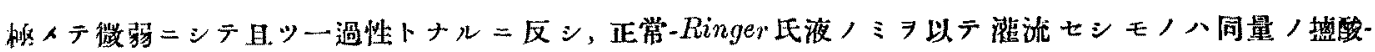

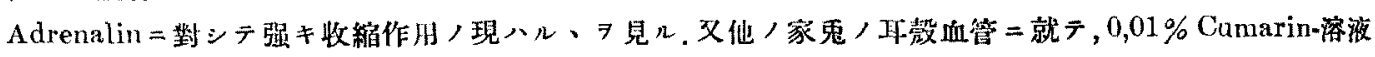

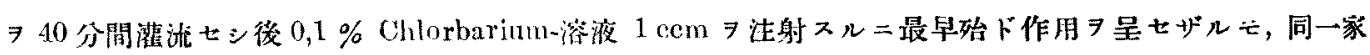

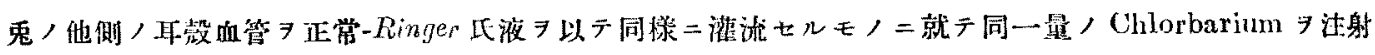

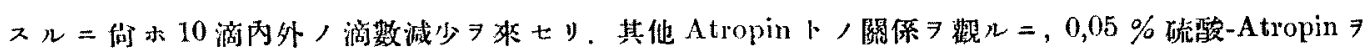

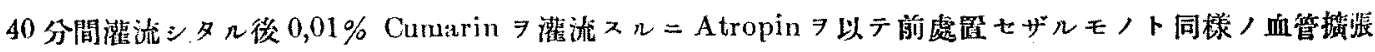
作用习見タリ。

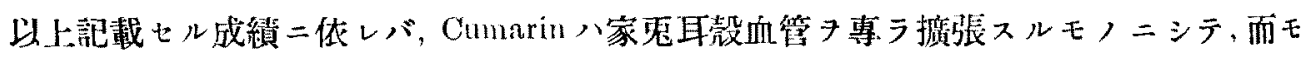

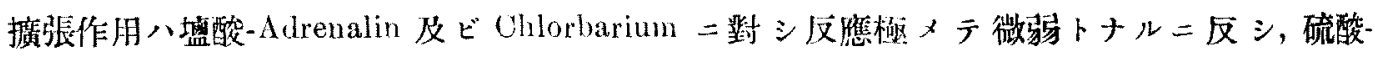
Atropin 二テ前處惪スルモ向本依然トシテ Chmarin 本來ノ血管拱張現象起ルヨリ察スレバ

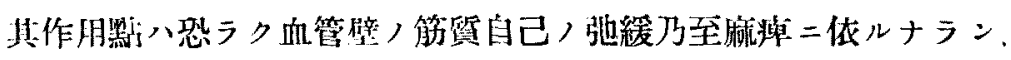

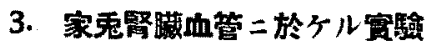

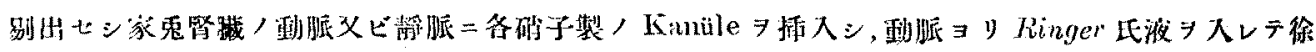

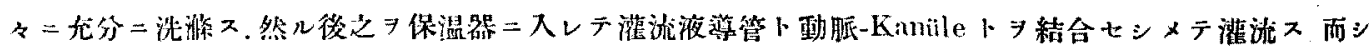

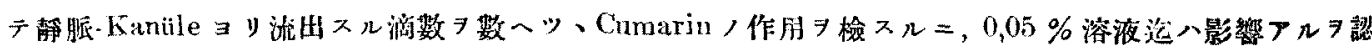

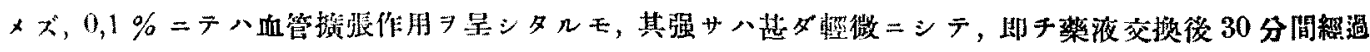
スれモ流出滴數八 5 滴以上增加スルコト哭シ。

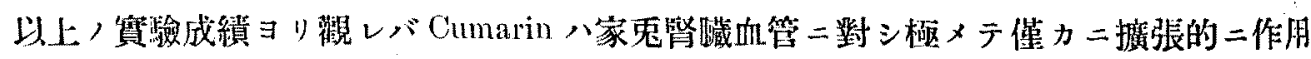
スルモノニシテ只其，强少、他，㿼管二對スル如ク强カラザルナリ．

\section{4. 家鬼冠狀血管二於ケル實驗}

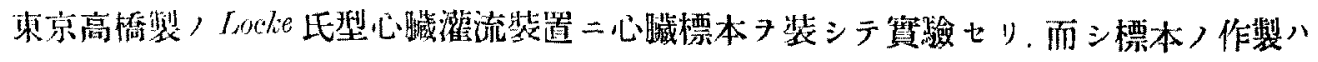


Laingendor ff-Kraukowe氏法二依り直于二大動脈內二硝子製，Kaü̈le 7 㨂入三，家兔，剔出

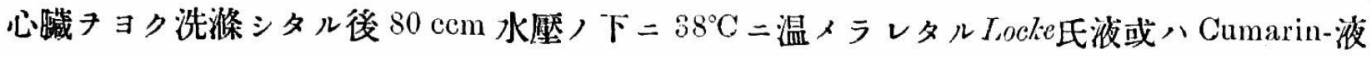

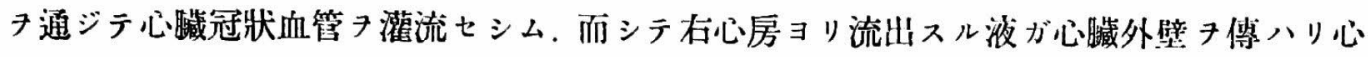

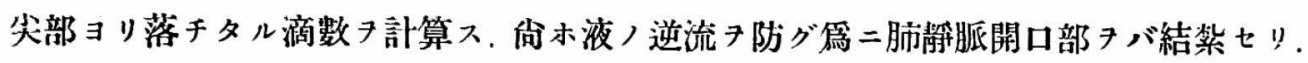

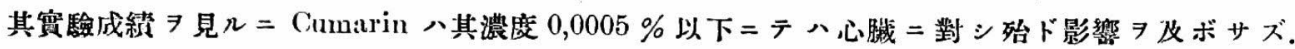

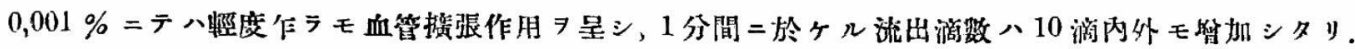

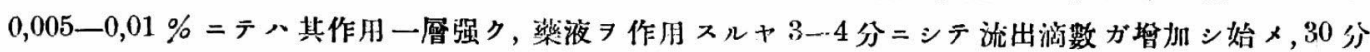

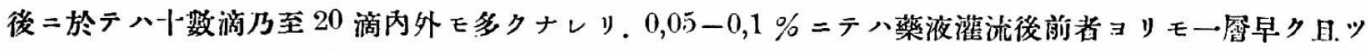

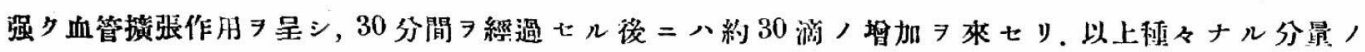
Cumarin $=$ 血管，援張セルモノ $=, L s c k$ 氏液 ニシテ原狀: =杘ル.

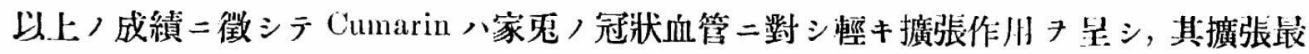
小有效量ハ $0,001 \%$ \% 。

\section{V. 滑平荕藏器及ビ蝶蚓筋ニ及ボス作用}

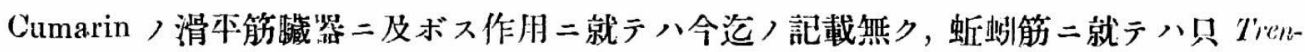

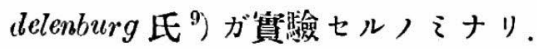

余ハ本章二於テ Magnus 氏法二從七Cumarin，程々ナル剔出滑本筋臟器及ビ蚚蛅筋二 對スル作用 檢セリ。

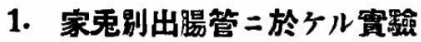

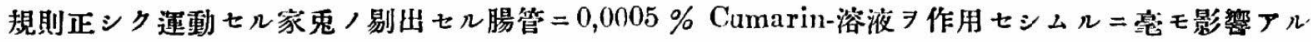

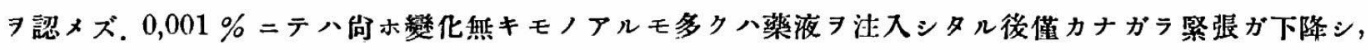

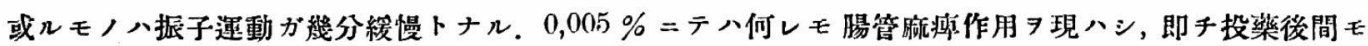
ナク緊張ハ僌ク下降シ, 振子運動モ亦徐々トナリ, 從ツテ其振幅モ稍々炏小トナル。然レドモ後二八治ド 完全二㤇復ス，0,01\%=テハ其作用一層强クシテ緊張下降八著シク戈リ，振子運動ノ頻度モ減シ，振幅

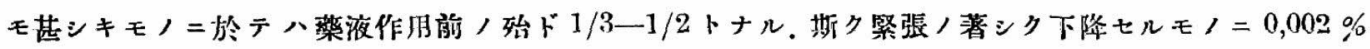

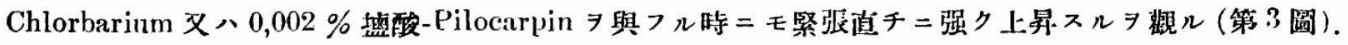

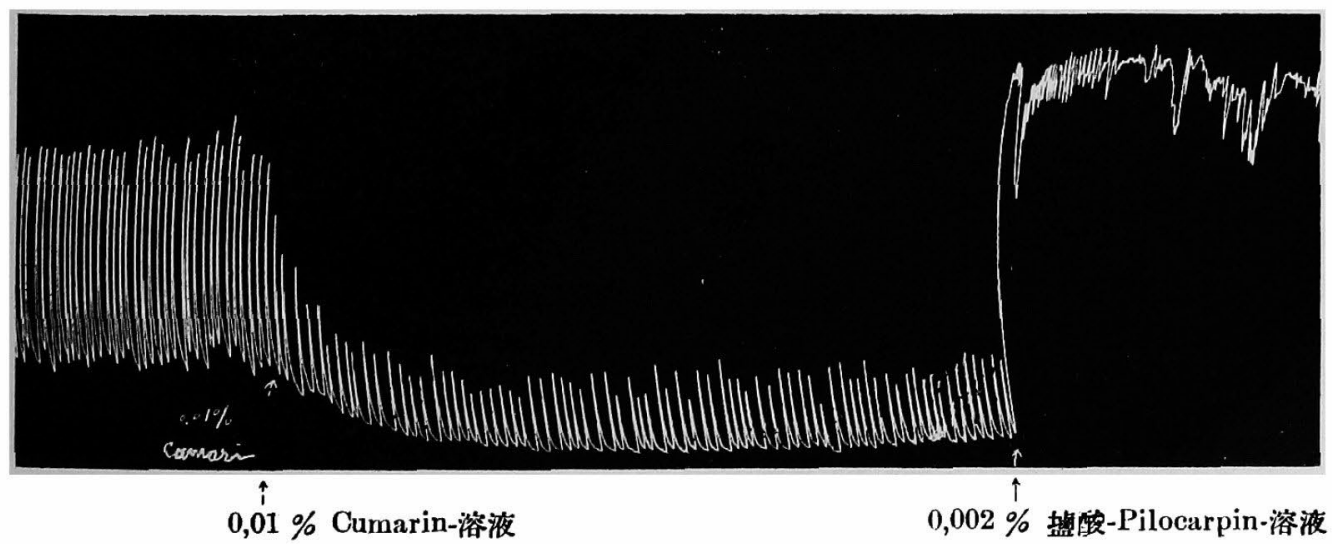

第 3 圖，家兔腸管曲線。 


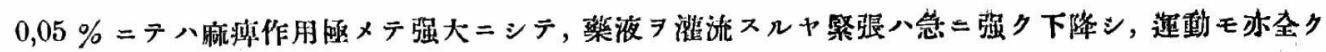

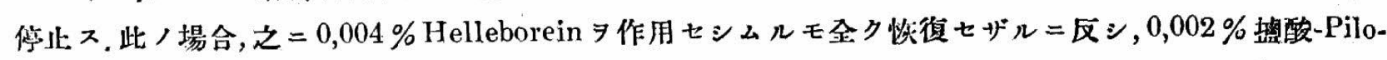

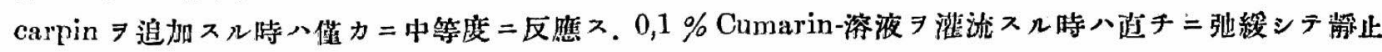

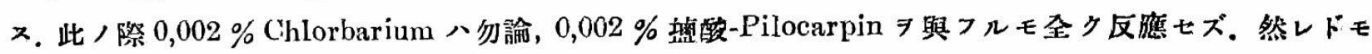

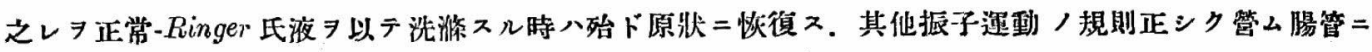

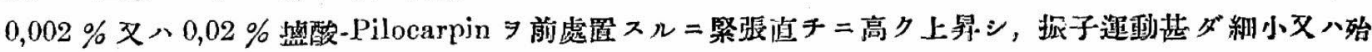

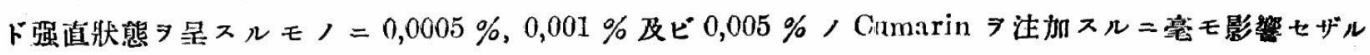
二反シ, そ $=0,002 \%$ 硫酸-Atropin $ヨ$ 與フレパ緊張直チー下降シ, 振子荤動モ亦次第二或儿程度迄现八 几、ヨ觀ルナリ。

以上ノ結果ヨリ觀レバCumarin，家鬼腸管二對シ, 專ラ麻㯅的二作用スルモノニシテ,

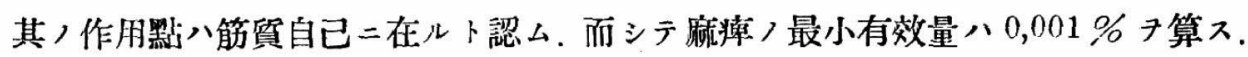

\section{2. 家鬼别出子宮二於ケル嘪驗}

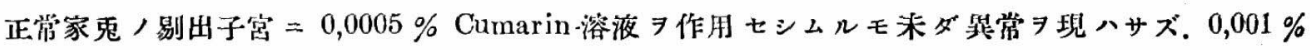

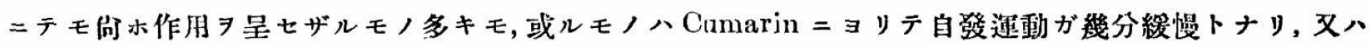

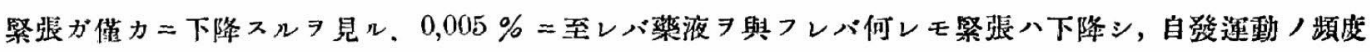

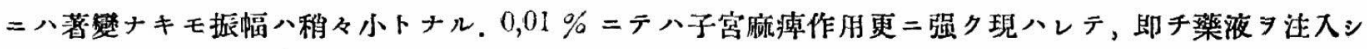

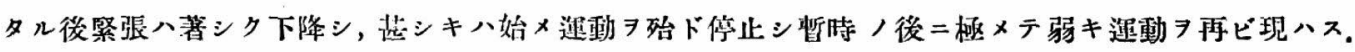

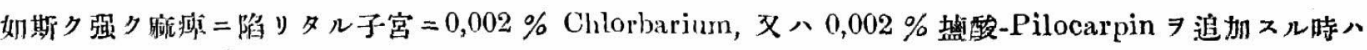

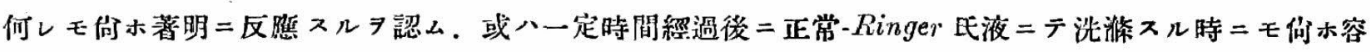

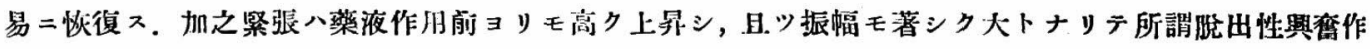

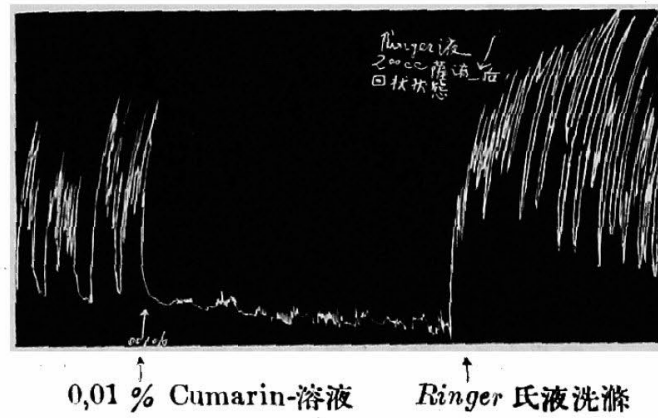

第 4 圖。家鬼子宮曲線。 用习來ス 7 目繁又 (第 4 圖)。

又 $0,02 \%$ 搵酸-Pilocarpin =テ强ク緊張 ノ上 昇七几子宮 $=0,0005-0,001 \%$ Cumarin-溶液 7 與 フルニ茎モ影響ナキ二反シ，0,002\%硫酸-Atropin ヨ注加スレバ直チニ緊張ガ下降シテ最初全ク静止 スルモ, 凡ン2-3分後二再ビ頻數ニシテ小サキ振

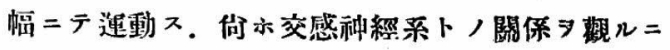
先ヅ酒石酸-Nicotin $\rightarrow$ 给 $\times 0,05 \%$ 作用七シメタル 後, 再庭 $0,1025 \%$ 與へテ最早異常 7 呈セザルモ つ $=0,005-0,01 \%$ Cumarin-溶液 7 迫加 $ス 几$ 時 $=$

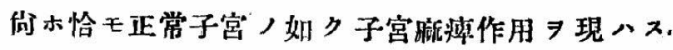

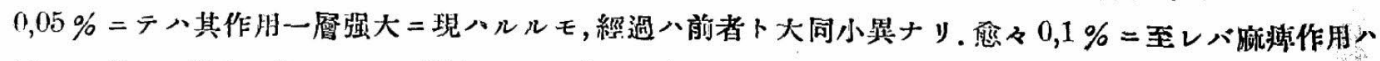

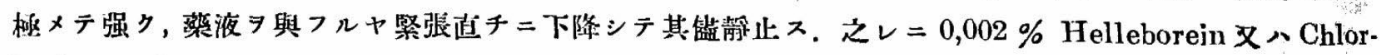
barium $尹$ 作用セシムルモ最早全ク反應ヨ呈セザルナリ.

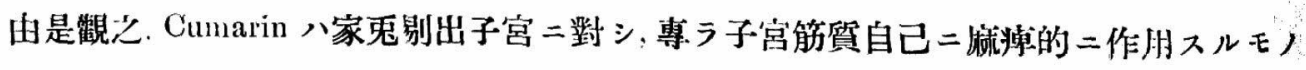
ナリ。而シテ䴢源ノ最小有效量ハ $0,001 \%$ ナリ。

\section{3. 水蛙剔出胃二於ケル苗䮦}

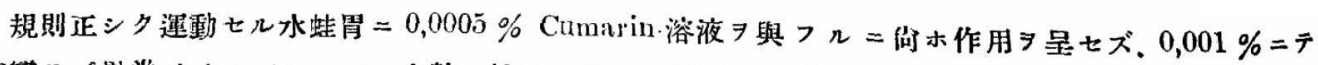

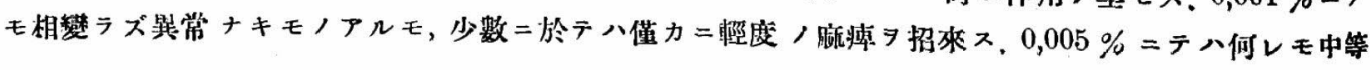




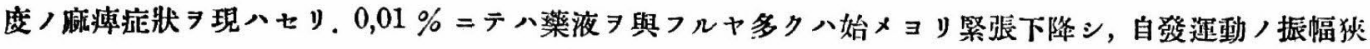

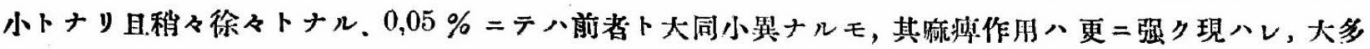
数二於テ緊張下降卜共二運動停止 7 來 . 斯ク運動ノ停止七几モ/ $0,002 \%$ Chlorbarium 又八 Helle-

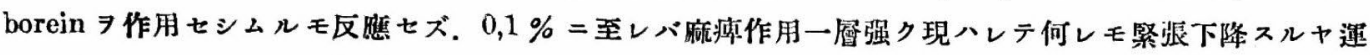
動ハ全ク止マレリ. 以上 $0,05-0,1 \%$ Cumarin 溶液ニテ连動 全ク停止七ルモノ=, 正常-Ringer 氏液

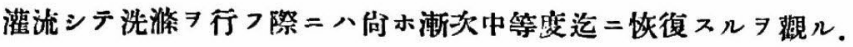

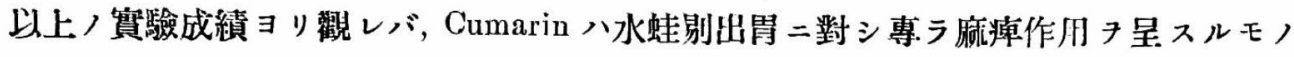
ナリ、魔㾇最小有效量ハ $0,001 \%$ 算スルナリ。

\section{4. 水蛙剔出腸管二於ケル實驗}

0,0001\% Cumarin-溶液ハ水蛙剔出腸管二對シ何等作用セザルナリ。 $0,0005 \%=$ モ何ホ影響 7 呈

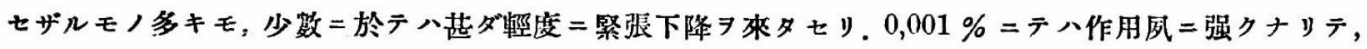
藥液ノ注加二依り緊張八著明二下隆セり. 併シ自發傕動ノ頻度及ビ振幅二、 Cumarin-作用前卜大差ナ

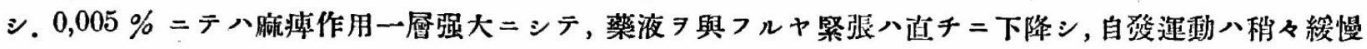

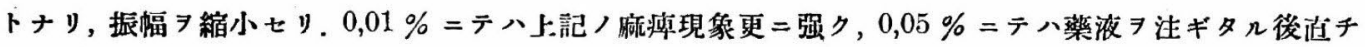

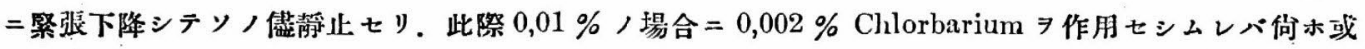
几程度迄再ビ運動スルヨ觀ルナリ. 又此等濃度ノCumarin=依りテ青止セルモノ=, 正常-Ringer 比液

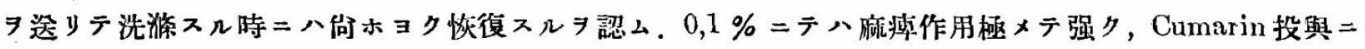
ヨリテ直チニ完全麻瘦二陷レリ. 此際正常-Ringer 氏液, 洗滌ヨ行フモ最早烣復セザルナリ.

上記，成績二依レバ, Cumarin 八水蛙剔出腸管二對シ專ラ麻㽽的二作用スルモノニシ テ, 其麼渒最小有效量ハ $0,0005 \%$ ナリ。

\section{5. 蛲蚓湤ニ於ケル富驗}

Trendelenburg 氏 $\left.{ }^{9}\right)$ 二從へバ Cumarin 八分離セル虹蚹筋二對シ小量ニテハ興億シ, 大量

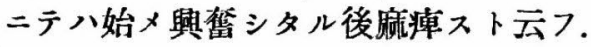

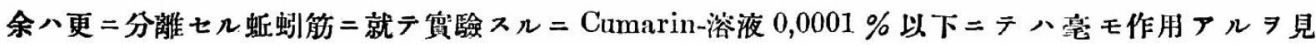
ズ.0,0005\%=テハ份木變化無キモノアルモ,或几モノ、Cumarin=依リテ自發荤動明カ二頻數トナル

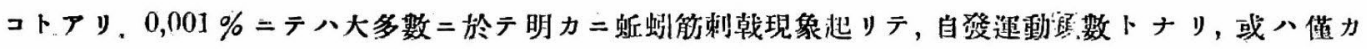
=緊张上昇ス. $0,005 \%=$ 八薬液 7 與へタル後多ク八徐々二緊张上昇シ，自發荤動モ頻數トナリテ中

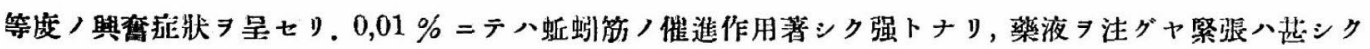
上昇シ, 且”速カ二荤動シ, 自發连動ノ振幅モ非常ニ大トナル 認么 (第 5 圆). 而モ大多數=於テ此症

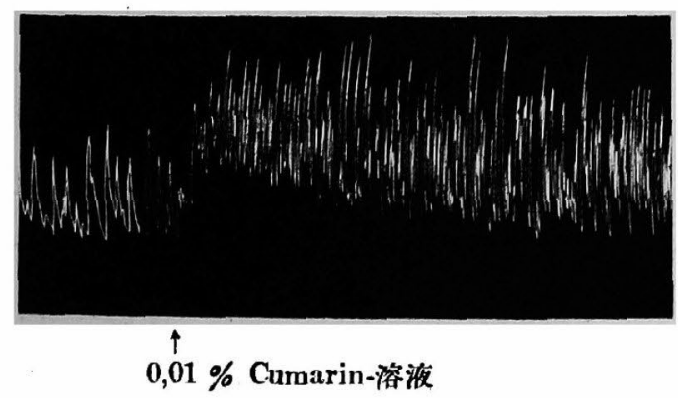

茅 5 圖. 䗒蚛筋曲線. 狀 $\exists$ 長ク持䋶スルモ, 少数 $=$ 於テハ後 $=$ 却テ緊張

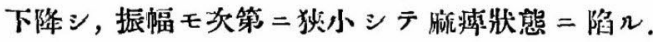

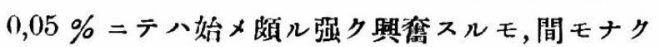
緊张下降シテ自發運動八漸次絽慢トナリ，振幅も 次第二狄小シテ遂二八特 $=$ 運動停止 セントスル モノアリ。 $0,1 \%=$ テ始メ，興巂作用及ビ後，

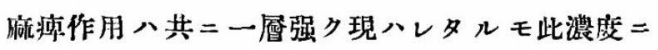
於テ運動ノ全ク停止セルモノニテモ正常-Ringer

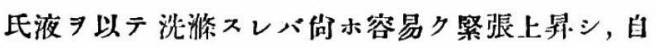
资運動モ營ミテ再ビ恢復ス。 


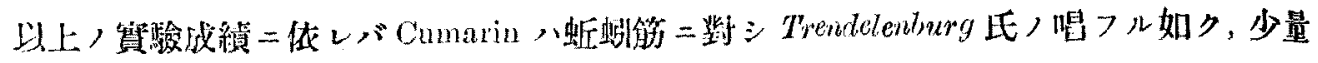

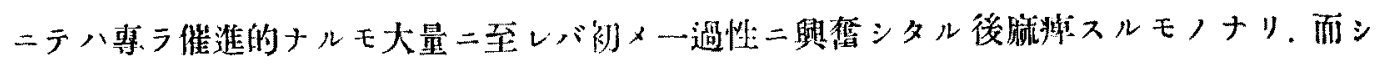

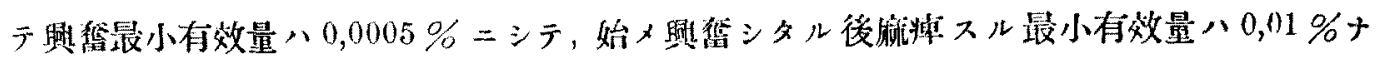
リ.

\section{V1. 水蛙骨骼矨二及ボス作用}

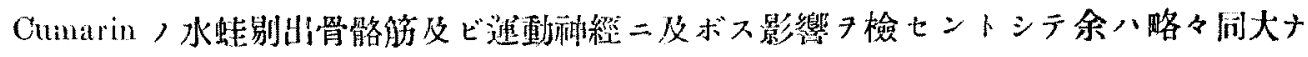

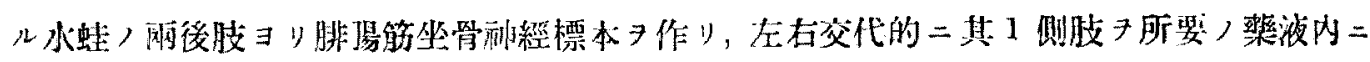

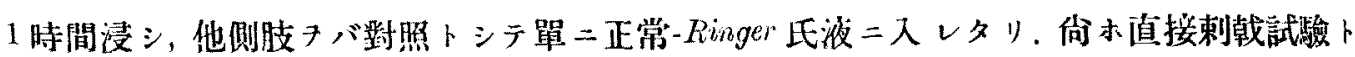

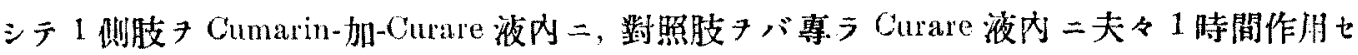

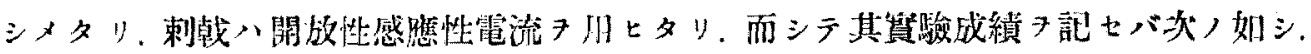

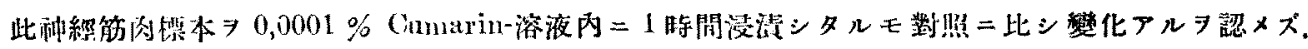

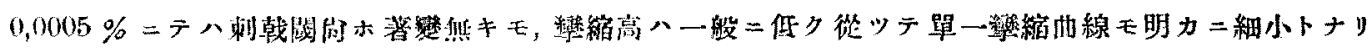

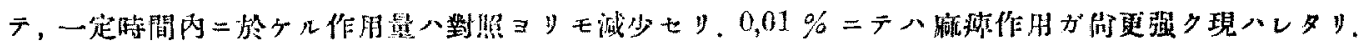

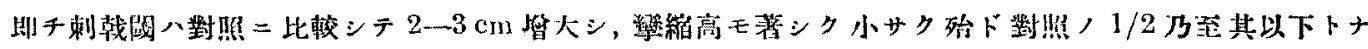

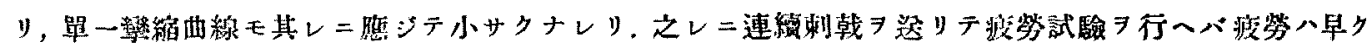

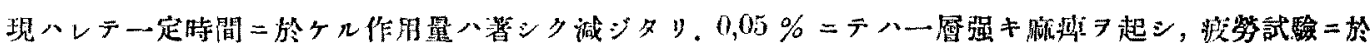

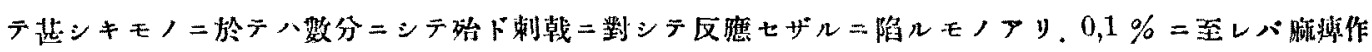

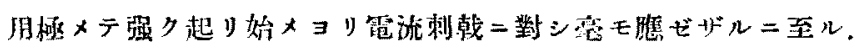

\section{直挼刺戟試驗.}

Cumain $0,001 \%$ 溶液二テ1時間作用せシムルモ招木買常

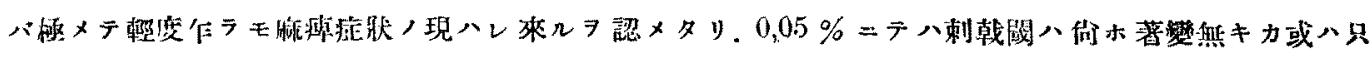

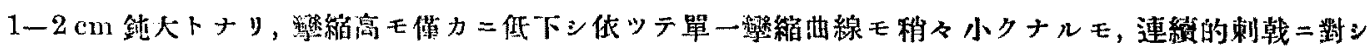

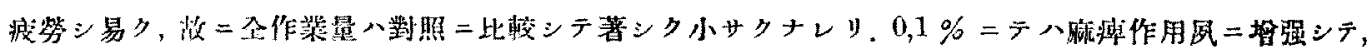

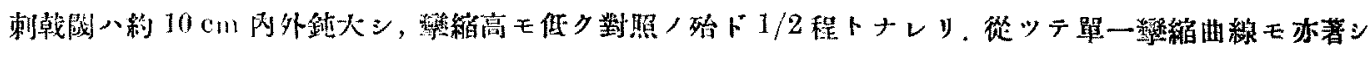

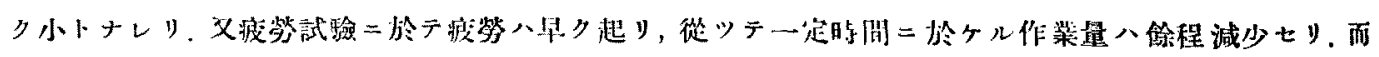

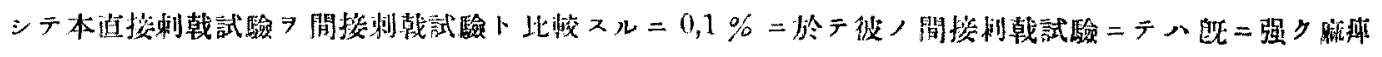

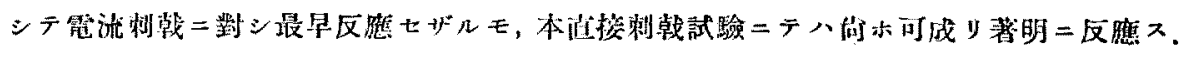

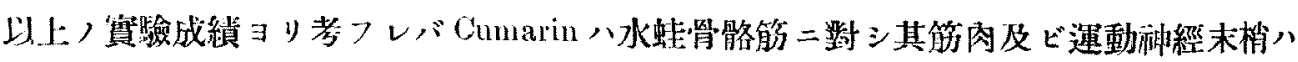
共二最初ヨリ虱淿七ラル、モノニシテ, 殊二後者八前者ヨリモ著シク强ク犯サル、ナリ。

\section{概 括}

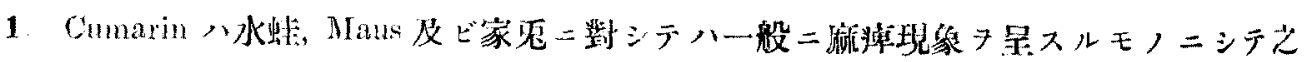

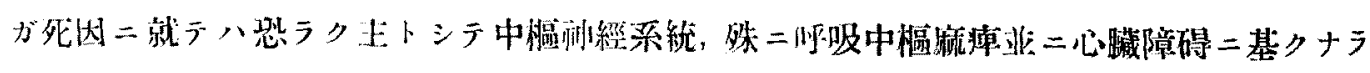

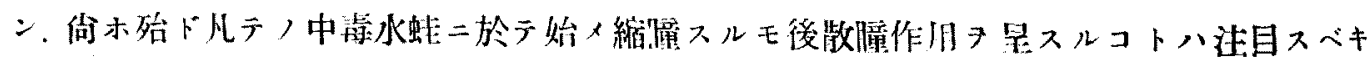

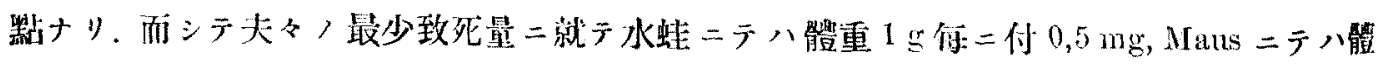

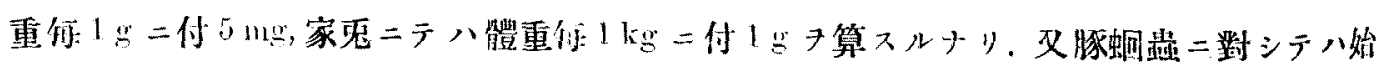




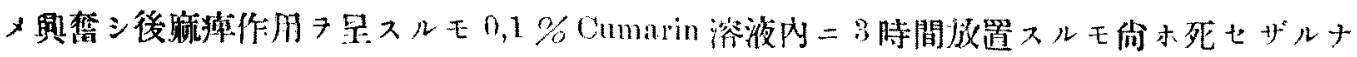
リ.

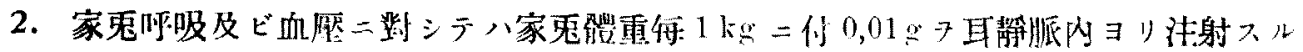
モ台ホ影響子呈セズ.

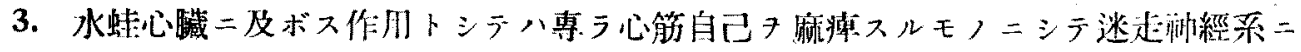

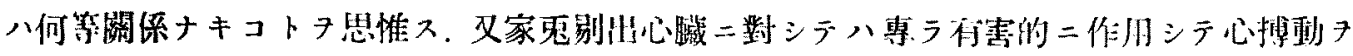
障碍乃至停止二至ラシム。

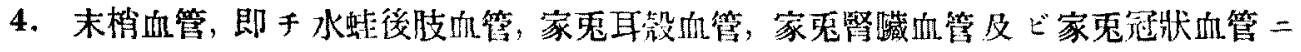

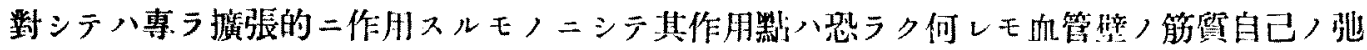

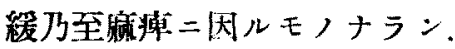

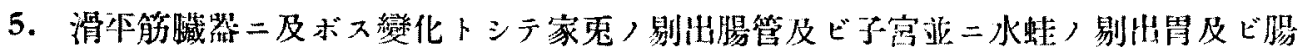

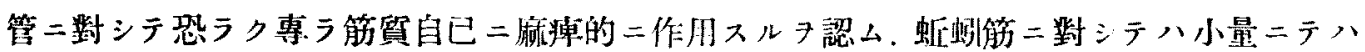

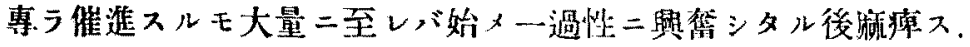

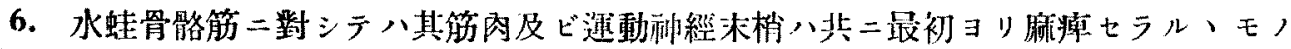
ニシテ，殊二後者ハ前者ヨリモ著シク犯サル、ナリ。

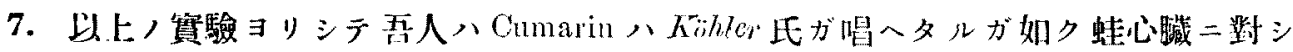

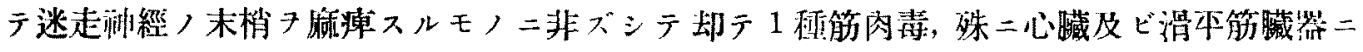

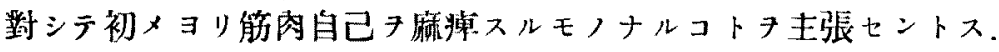

\section{引用書 目}

1) Schmidt, E.: Pharmazent. Chenie 2, $1294(1923)$.

2) Köhler, H.: Centralbl. med. Wissensch. 1875, 867.

3) Harnack, F. u. Witkowshi: A rch. f. exp. Pathol. a. Pharmakol. 5, 429 (1876).

4) Köhler $H$. : Ebenda 6, 283(1877).

5) Winternitz, $R$ : Ebenda 35, 77 (1895).

6) Fllinger, $A$ : Edenda, Supplementband $150(1908)$.

7) Buchkeim u. Malewski: Zit. n. Iyllinger (6).

8) Cianci; Giornale Internat. de 1a Scienza Med. 1908. Zit. n. Fränkel, S., Die A rzmcimittelsynthese 4. Aufl., 504 (1919).

9) Trendelenburg, P.: Arch. f. exp. Pathol. n. Pharmakol. 79, 214 (1916), 